\title{
Bitki Kromozomlarında Sentromerlerin Önemi, Moleküler Yapısı ve Organizasyonu
}

\author{
Importance, Molecular Structure and Organization of Centromeres in Plant \\ Chromosomes
}

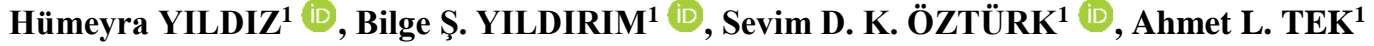 \\ ${ }^{1}$ Niğde Ömer Halisdemir Üniversitesi, Ayhan Şahenk Tarım Bilimleri ve Teknolojileri Fakültesi, Tarımsal \\ Genetik Mühendisliği Bölümü, Tarımsal Biyoinformatik Anabilim Dalı, 51240, Niğde
}

\begin{abstract}
Öz
Sentromer hücre bölünmesi esnasında mikrotübüller aracılığıyla kromozomların yeni hücrelere eşit dağılımını sağlayan kompleks bir yapıdır. Böylesi bir kompleks yapı, tüm ökaryotlarda olduğu gibi bitki türlerinde de büyük ilgi çekerek farklı çalışma disiplinlerinin temelini oluşturmuştur. Çalışma disiplinlerinden birisi olan bitki sentromer biyolojisi, çeşitli bitki sentromerlerindeki benzerlik ve farklılıkları ortaya koyarak genom biyolojisi, taksonomi, filogeni gibi alanlara temel bilgiler sunmaktadır. Ökaryotlarda kromozomları üzerinde fonksiyonel olarak korunmuş sentromer, yapısal anlamda farklı özellikler gösterebilmektedir. Bu yapısal değişiklikler en yaygın anlamda iki yapısal unsur olan sentromere özgü histon $\mathrm{H} 3$ (CENH3) proteini ve sentromerik DNA dizileri bakımından ifade edilmektedir. Sentromer tiplerinin karakteristik yapısal özelliklerinin tanımlanabilmesi için klonlanarak dizilenmesi gerekmektedir. Ancak sentromerik DNA dizilerinde bulunan uzun tekrar DNA elementlerinden dolayı hatalı dizilemeler meydana gelebilmekte ve doğru fiziksel haritalar oluşturulamamaktadır. Bu nedenle bitki sentromer evrimi yeteri kadar çözümlenememiştir. Bitki sentromerini çözümleyebilmek amaciyla sentromer mühendisliği, bitki biyoteknolojisi ve biyoinformatik alanları birbiriyle entegre edilerek yeni analiz yöntemleri geliştirilmiştir. Bu çalışma kapsamında, tarihsel perspektiften yola çıkarak çeşitli model bitkiler ve devamında baklagiller (Fabaceae) özelinde farklı epigenetik özellikteki sentromerik DNA dizileri ve sentromer proteinleri irdelenerek evrensel bitki sentromer yapısının özellikleri ortaya konulacaktır. Ayrıca sentromer mühendisliği aracılığıyla uygulamalı tarım bilimlerinde bitki 1slahına büyük yenilikler katabilecek farklı bilimsel çalışmalar sunulacaktır.
\end{abstract}

Anahtar Kelimeler: ardışık tekrarlar, CENH3, epigenetik, kinetokor, kromozom, sentromer mühendisliği.

\begin{abstract}
Centromere is a complex structure that ensures equal distribution of chromosomes to new cells via microtubules during cell division. Such a complex structure attracted great attention in plant species as well as in all eukaryotes and formed the basis of various study disciplines. Plant centromere biology, which is one of the study disciplines, provides basic information on genome biology, taxonomy, phylogeny by revealing the similarities and differences in various plant centromeres. In eukaryotes, the centromere, which is functionally conserved on chromosomes, may show various structural features. These structural changes are most commonly expressed in terms of the centromere-specific histone H3 (CENH3) protein and centromeric DNA sequences, which are two structural elements. To define the characteristic structural features of the centromere types, extensive studies must be performed involving cloning and sequencing. However, due to the long repeat DNA elements present in centromeric regions, erroneous sequences may occur and correct physical and genetic maps cannot be created. Therefore, plant centromere evolution has not been sufficiently resolved. To analyze the plant centromeres, new analysis methods have been developed by integrating the fields of centromere engineering, plant biotechnology and bioinformatics. Within the scope of this review, starting from a historical perspective, the centromere DNA sequences and centromere proteins with different epigenetic properties will be examined for various model plants and with special emphasis to legumes (Fabaceae), and the properties of the universal plant centromere structure will be revealed. In addition, different scientific studies will be presented that can add great innovations to plant breeding in applied agricultural sciences through centromere engineering.
\end{abstract}

Keywords: tandem repeats, CENH3, epigenetics, kinetochore, chromosome, centromere engineering.

\section{GİRIŞ}

Hücre bölünmesi, tek hücreli canlılarda yeni bir organizmanın üremesini sağlarken, çok hücreli canlılarda bölünme sonrası oluşan yeni hücrelerle birlikte doku ve organları meydana getirmektedir. Her iki hücre bölünmesiyle üreme ve çoğalma esnasında genetik bilginin sekteye uğramadan aktarımı büyüme ve gelişim için vazgeçilmezdir. Genetik bilgi nesilden nesile, kalıtım materyali olan deoksiribonükleik asit (DNA) molekülünün birbirinden bağımsız birimler şeklinde paketlenerek kromozomlar formunda yeni üretilen kardeş hücrelere aktarılmasıyla sağlanmaktadır [1,2]. Teknik olarak, kromozomlar, somatik ve eşey hücrelerinde sırasıyla mitoz ve mayoz bölünme esnasında kalıtım materyalinin aktarımından sorumludur. Kromozomların fonksiyonel yapı taşları olan sentromer, telomer ve DNA replikasyon bölgelerinin moleküler düzeyde daha iyi anlaşılması yeni 
ortaya çıkan hücrelerin sağlıklı formda bulunması için gereklidir. $\mathrm{Bu}$ yapısal bölgeler içerisinde özellikle sentromer büyük bir ilgi çekmektedir ve yoğun çalışma disiplinini oluşturmaktadır. $\mathrm{Bu}$ bağlamda, bitki sentromerleri özelinde öncelikle model bitkiler ve baklagiller kapsamında temel tanımlamalar yapılacaktır. Ayrıca tarihsel perspektiften yola çıkarak farklı bitki türlerinden elde edilen güncel yapısal özelliklerin incelendiği çalışmaları entegre eden moleküler kompleks bir yapı ortaya konulacaktır. Şu ana kadar elde edilen bulgulardan yola çıkarak bu kompleks hücresel yapının temel bilimlerden başlayıp moleküler bitki ıslahını kapsayan ve gelecekte tarıma dahil edilebilecek yönlerinden bahsedilecektir. Bunun sonucunda, bu alanda çalışan ve çalışacak olan bilim insanlarına temel referans oluşturacak kritik irdelemelere sahip bir analiz ortaya konulacaktır.

\subsection{Sentromer nedir?}

Sentromer, hücre bölünmesi esnasında kinetokor aracılığıyla mikrotübüllerin bağlanma bölgesi olarak işlev görerek kromozomların yeni hücrelere eşit dağılımını sağlamaktadır (Şekil 1B). Klasik sitogenetik çalışmalar açısından sentromer, kromozom üzerindeki birincil (primer) boğum olarak tanımlanmaktadır [3]. Moleküler sitogenetik olarak başka bir açıdan bakıldığında ise sentromer, kromozom üzerinde bulunan heterokromatik bir bloğa denk gelmektedir [4]. Biyokimyasal perspektiften değerlendirildiğinde sentromer, kinetokor olarak tanımlanan protein kompleksinin mikrotübül ve kromozomal DNA arasında bağlantı kurduğu interaktif bir yapıya işaret etmektedir [5]. Genetik açıdan değerlendirildiğinde, açılım gösteren bir popülasyon üzerinde rekombinasyona dayalı DNA markörleriyle geliştirilen genetik haritalarda; her bir kromozom üzerinde özellikle rekombinasyonun ya tamamen olmadığı ya da son derece sınırlı gerçekleştiği kromozomal lokusu ifade etmektedir. Genetik haritalarda böylesi bir kromozomal lokus fiziksel olarak en az 1-2 Mb uzunluğuna tekabül etmektedir [6]. Sonuç olarak, klasik sitogenetik, moleküler sitogenetik, biyokimyasal ve genetik anlamda sentromer her ne kadar farklı tanımlamalarla ifade edilsede, bu durum sentromerin yapısal önemini değiştirmemektedir. Tüm ökaryotik organizmalarda korunmuş olması sebebiyle sentromer, kromozomların tanımlanmasında ve karyotip analizlerinde oldukça irdelenen kompleks bir yapidir.

\subsection{Sentromer ve karyotip ilişkisi}

Ökaryotik bir organizmanın somatik hücrelerinde her bir kromozom, benzeşik bir homoloğuyla beraber bir çift kromozom seti oluşturur. Bir hücredeki somatik metafaz kromozomların homologlarıyla beraber uzun olandan kısa olana doğru siralandığı görsel sunuma karyotip denir. Karyotipleme yapılırken özellikle kromozomların sayısı, boyutu ve şekli gibi farklı morfolojik özellikleri dikkate alınmaktadır. Karyotipi oluşturan kromozomların boyutuna, sentromerin kromozom üzerindeki konumuna, kromozom çiftlerinin uzun ve kısa kollarının birbirine oranlarına göre yapılmış şematik gruplandırmalara ise idiogram denilmektedir [7]. 1970'li y1llarda ilk kromozom çalışmaları ile somatik metafaz kromozomları asetokarmin, feulgen gibi boyalarla karakteristik özellikleri ortaya çıkartılacak şekilde boyanmıştır. Boyama yapıldıktan sonra elde edilen karakteristik bantlar yardımıyla ilk karyotipik analizler oluşturulmuştur. $\mathrm{Bu}$ analizler başlangıçta insan ve hayvan somatik dokularında başlamış olup daha sonra bitki kök ucu gibi hızlı gelişen meristematik dokularda incelenerek devam edilmiştir. Daha ayrıntılı karyotip analizleri için Q (Quinacrine), G (Giemsa), R (Reverse), C (sentromerik bölge), T (telomerik bölge) gibi aynı veya farklı bölgeleri hedef alan özgün bantlama teknikleri geliştirilmiştir [7, 8]. Günümüzde ise DNA-DNA hibridizasyon teknikleri yardımıyla DNA dizi bölgelerini tanımlayan FISH (Floresan in situ hibridizasyonu) ve GISH (Genomik in situ hibridizasyonu) gibi yöntemler ile karyotipleme çalışmalarına devam edilmektedir [2].

Bir türün evrimsel olarak başarılı olabilmesi ve devamlılık gösterebilmesi için tür içinde karyotip yapısının korunmuş ve sabit olması gerekmektedir. Ökaryotik organizmalarda, kromozom üzerindeki sentromerin yeri evrimsel olarak korunmuştur ve her bir sentromerin yeri kromozom üzerinde sabittir. Bir kromozom üzerinde sentromerin yerinin değişmesi üreme izolasyonu (reproductive isolation) sonucu evrimsel olarak yeni tür oluşmasını sağlamaktadır. Hatta sentromerin yerinin değişmesi iki tür arasında bile üreme izolasyonuna sebep olabilmektedir. Dolayısıyla, kromozom üzerinde sentromer pozisyonunun değişimiyle yeni bir tür oluşumu arasında yakın nedensellik ilişkisi mevcuttur [9].

Tüm ökaryotik organizmalarda, kromozom içi ve kromozomlar arası yeniden düzenlemeler nedeniyle genotipik ve fenotipik farklılıklar oluşabilmektedir. $\mathrm{Bu}$ genotipik farklılıklar hem kromozom organizasyonunda hem de sayısında değişiklikler içerebilmektedir. Değişikliklerin tespiti için karyotip evrimi, sitogenetik haritalamalar, karşılaştırmalı genetik ve genomik analizler gibi farklı teknik ve teknolojilerden faydalanılmaktadır $\quad[10,11]$. Kromozomlar üzerinde değişken yapısal bölgelerin analiz edildiği farklı yöntemlerle kromozom yapısı anlaşılarak farklı organizmaların karyotip evrimi hakkında ayrıntılı mekanizmalar ortaya çıkarılabilmektedir. Karyotip çalışmalarında sentromer bölgesi, birincil referans olup güncel evrimsel çalışmalar bakımından hedef tema haline gelmiştir. Tür düzeyinde kromozom üzerinde korunmuş pozisyonda bulunan sentromerde meydana gelebilecek değişiklikler, türleşme, disentrik kromozom oluşumu, karyotip sayı değişimi gibi farklı evrimsel sonuçlar ortaya koymaktadır $[9,12]$. Bu yüzden sentromer yapısını ve özelliklerini anlamak genom, taksonomi, filogeni ve benzeri alanlarda yapılacak çalışmalara yol gösterici niteliktedir. 


\subsection{Yapısal özelliklerine göre sentromer tipleri}

Sentromer bir organizmada kromozom üzerinde bulunduğu konum ve büyüklük açısından farklı yapısal gruplandırmalarla tanımlanmıştır. Farklı ökaryotik türlerde görülen sentromer özelliklerindeki değişiklikler sebebiyle sentromerler farklı isimlerle anılabilmektedir. Bu sebeple, en genel özelliklerine göre sentromerler, nokta sentromer, bölgesel sentromer, holosentromer ve neosentromer olarak ifade edilebilir [13, 14] (Şekil 1A). Bu sentromer tipleri kısaca aşağıda açıklanmıştır.

Nokta sentromeri, ilk olarak Saccharomyces cerevisiae adı verilen tomurcuklanarak çoğalan maya türünde keşfedilmiş özel bir sentromer tipidir. Bu sentromer tipi tekrarlayan DNA dizileri içermemektedir ve bu özellik nokta sentromerler için ayırt edicidir (Tablo 1). Birincil boğum içeren nokta sentromer, tek mikrotübül ve mikrotübül ile bağlantılı yaklaşık 125 baz çiftinden oluşan 3 adet korunmuş DNA elementinden oluşmaktadır [13, 15]. Diğer sentromer tiplerine göre içeriğindeki DNA dizisinden dolayı daha küçük bir yapıya sahiptir ve dizi bilgisine bakılarak bu sentromer tipi tanımlanabilmektedir. Mayalarda sentromerik protein olarak bilinen CSE4 proteini [16] ile nokta sentromerler tanımlanmaktadır. Sentromeri tanımlayan CSE4 proteininin bulunduğu histon oktomerini 3 adet sentromerde bulunan korunmuş DNA elementleri çevrelemektedir [15]. Bu korunmuş elementler sentromerin fonksiyonu etkileyerek daha doğru bir kromozom ayrışmasını sağlamaktadır [17].

İkinci tip olan bölgesel sentromerler, birçok ökaryotik organizmada kromozom üzerinde belirli bir bölgede dağılım gösteren kinetokor proteinlerinden oluşmaktadır (Şekil 1A). Ökaryotlarda genellikle içeriğindeki DNA miktarı fazla olduğu için kilobaz veya megabaz cinsinden tanımlanan bölgesel sentromer, ilk olarak sentromerik tekrar dizileri çalışılırken Schizosaccharomyces pombe fisyon mayasında keşfedilmiştir [15]. Bölgesel sentromerler genellikle ardışık tekrarlayan DNA dizilerinden oluşmakta ve nokta sentromerlerin aksine kinetokor proteinlerine birden fazla mikrotübül bağlanmaktadır $[13,15]$ (Şekil 1A).

İğ ipliklerinin tüm kromozom boyunca birden fazla sentromerik bölgede bulunduğu ve birincil boğumu olmayan sentromer tipi ise holosentromerlerdir (Şekil 1A; Tablo 1). Bölünme esnasında atasal bir sentromere sahip kromozomun herhangi bir bölgesinde meydana gelen DNA çift sarmalındaki kırılmalar sonucunda parça kayıpları oluşabilmektedir. Ancak holosentrik sentromere sahip organizmaların iğ ipliklerinin yayılım göstermesi ve iğ ipliklerinde kopmayı önleyici yapışkan uçların bulunması sayesinde parça kayıplarını engellendiği, kolların doğru ayrışmasını sağladığı ve kinetik aktiviteyi koruduğu öngörülmektedir [18, 19]. Gösterdiği kinetik aktiviteden dolayı holokinetik kromozom olarak da tanımlanmaktadır. Holokinetik kromozomlarda oluşan kırılmalar sonucu parçaların ayrılması ya da başka kromozomlarla birleşmesi ile kromozom sayısında değişiklikler yaratmaktadır. Böylece, kromozom sayılarında oluşan değişikliklerin genetik varyasyon oluşturarak türleşme üzerinde etkisi olduğu düşünülmektedir [19].

Son tip olan neosentromerler, sentromerik olmayan kromozom bölgelerinde oluşan yeni sentromerlerdir. Neosentromer oluşumu sırasında, atasal sentromer kromozom üzerinde kalmakta ancak mikrotübüllerle birlikte, kinetokor proteinleri de yeni oluşan sentromer üzerine bağlanmaktadır. Yeni oluşan sentromerde sentromerik satellit DNA dizileri bulunmazken atasal sentromer içeriğinde bu diziler varlığını sürdürmektedir [20]. Bitkilerde neosentromer tipine örnek olarak buğday üzerinde yapılan bir çalışmada satellit DNA dizileri olmadan da fonksiyonel sentromer organizasyonun neosentromerler üzerinde oluşabildiği gösterilmiştir [21]. Buğday neosentromerinin aksine, misır neosentromeri, heterokromatin knob adi verilen rastgele DNA tekrarların ve ek dizilerin birleşmesinden oluşan yapı ile ilişkilendirildiğinden, söz konusu DNA tekrarların yokluğunda neosentromer aktivitesi gözlenmemektedir [22].

Sentromer ilk olarak 1880 yılında Flemming tarafindan tespit edildiğinden beri birincil boğum olarak bilinmekteydi. Ancak günümüzde sentromerde fonksiyonel olan sentromere özgü histon H3 (CENH3) proteininin karakterize edilmesiyle bölgesel, neosentromer ve holosentromer gibi farklı sentromer tiplerinin keşfedilmesi daha kolay olmuştur. Organizmalar arasında yüksek düzeyde korunmuş CENH3 proteinin ve etkileşimde olduğu sentromerik DNA dizilerin tanımlanması sentromer yap1 ve işlevinin anlaşılır hale gelmesini sağlamaktadır [13, 14, 59].

\subsection{Sentromerik DNA dizileri}

Tüm organizmaların hücre çekirdeğindeki genom yapısı farklı miktarlarda DNA kalıtım materyali içerebilmektedir. Hücre çekirdeğinde replike edilmemiş haploid DNA miktarı "C-değeri” olarak bilinmektedir. Ökaryotik genomlarda bulunan çok tekrarlayan DNA elementleri nedeniyle genom büyüklüğü ve organizma gelişmişliği arasında korelasyon eksikliği bulunmaktadır. Bu durum Cdeğeri paradoksu olarak adlandırılır. C-değeri paradoksu, çok fazla tekrar dizisi içermesi sebebiyle bitkilerde yaygın bulunan bir fenomendir [23, 24]. Şu ana kadar, bu paradoksun temeli henüz tam olarak anlaşılabilmiş değilse bile, bazı yeni çalışmalar bu istikametteki gelişmelere işaret etmektedir. Son zamanlarda yapılan çok sayıda araştırmada genler çoğunlukla sabit kalırken, genom boyutu varyasyonunun öncelikle tekrarlı DNA dizilerinin kademeli birikimi ve eliminasyonu ile yönlendirildiği 
kanıtlanmıştır [25]. $\mathrm{Bu}$ nedenle bitkilerde bulunan sentromerik ardışı tekrarların ve hareketli DNA elementlerin çeşitli aileleri, DNA dizi uzunlukları, genomda bulunma yüzdeleri, kromozom üzerindeki yayılımı gibi çeşitli yapısal özellikleri farklı perspektiflerden araştırılarak sunulmuştur.

Tablo 1. Yapısal özelliklere göre sınıflandırılan sentromer tiplerinin birbirleriyle karşılaştırılması

\begin{tabular}{|c|c|c|c|c|}
\hline $\begin{array}{l}\text { Sentromer tipi/ } \\
\text { Özellikleri }\end{array}$ & $\begin{array}{l}\text { Nokta } \\
\text { sentromer }\end{array}$ & Bölgesel sentromer & Holosentromer & Neosentromer \\
\hline Birincil boğum & Var & Var & Yok & Var \\
\hline $\begin{array}{c}\text { Ardışık tekrarlayan DNA } \\
\text { dizileri }\end{array}$ & Var & Var & Var & Yok \\
\hline $\begin{array}{l}\text { Sentomer mühendisliği } \\
\text { için kullanılabilir mi? }\end{array}$ & Hayır & Evet & Evet & Evet \\
\hline $\begin{array}{c}\text { Hücre bölünmesi } \\
\text { sırasında anomali olabilir } \\
\text { mi? }\end{array}$ & Evet & Evet & Yok & Evet \\
\hline $\begin{array}{c}\text { Sentromer belirleme } \\
\text { yöntemi }\end{array}$ & Dizi Bilgisi & $\begin{array}{l}\text { CenH3 İçeren } \\
\text { Nükleozom }\end{array}$ & $\begin{array}{l}\text { CenH3 İçeren } \\
\text { Nükleozom }\end{array}$ & $\begin{array}{l}\text { CenH3 İçeren } \\
\text { Nükleozom }\end{array}$ \\
\hline $\begin{array}{l}\text { Bitki sentromerler } \\
\text { örnekleri }\end{array}$ & - & $\begin{array}{c}\text { Lathyrus sativus } \\
{[111]}\end{array}$ & $\begin{array}{c}\text { Luzula elegans } \\
{[110]}\end{array}$ & $\begin{array}{c}\text { Oryza sativa } \\
{[66]}\end{array}$ \\
\hline
\end{tabular}

Ökaryotik sentromer yapılarının incelenmesi sonucu yüksek oranda tekrarlayan DNA dizilerinden oluştuğu kanısına varılmıştır. Tekrarlayan DNA dizilerinin oranı bir kromozom için ortalama $\% 5$ ile $\% 50$ arasında değiş̧ebilmektedir. Değişken oranda bulunan sentromerik DNA dizileri birçok farklı organizmada klonlanmış ve tanımlanmıştır (Tablo 2). Bu organizmalarda tanımlanan bazı sentromerik tekrarlar arasında kayda değer bir DNA dizi homolojisi tespit edilememiştir [3]. Böylesi filogenetik olarak farklı dağılım gösteren organizmalar arasında sentromerik DNA dizisi benzerliğinin bulunmaması genel kabul gören evrim teorisi ile çelişmektedir. Geleneksel evrim teorisine göre sentromer gibi tüm ökaryotik organizmalarda korunmuş olan bir yapının DNA kompozisyonunun da korunmuş olması beklenmektedir $[3,26]$.

\subsection{Transpozonlar ve sentromerik ardışık tekrarlar} (Tandem tekrarlar)

Geleneksel olarak çok uzun yıllardır sentromer ve perisentromer birçok organizmada heterokromatik yapıda olan aktif bir gen içeriği ve işlevi olmayan bölgeler olarak değerlendirilmiştir. $\mathrm{Bu}$ yüzden bu işlevsel bölgelerde yer alan DNA dizileri sessiz, transkripsiyonu olmayan, gen kodlamayan DNA dizileri, "junk DNA" veya "çöp DNA" gibi tabirlerle ifade edilmekteydi [27]. Ne var ki, son zamanlarda yapılan çalışmalar, bu düşünülenin tam aksini gösteren sonuçlar vermiştir [28]. Bu çalışmalarla birlikte sentromerik tekrarların sitoplazmik, hücresel ve gelişimsel etkileri tespit edilmiş̧ir. Ayrıca kromozom rekombinasyonu için de önemli olduğu bilgisi sunulmuştur [29].
Tekrarlayan DNA dizileri, genom içerisinde bulunuşları bakımından dağınık tekrarlar ve ardışık tekrarlar olmak üzere iki temel sınıfa ayrılmaktadır. Dağınık tekrarlar olarak bilinen transpozonlar, kodlama dizilerinin yapısı, uzunluğu, kararlılığı ve transpozisyon mekanizmalarına göre kendi içerisinde farklı gruplara ayrılabilmektedir. Ardışık tekrarlar ise, tekrarlayan DNA molekülünün monomer uzunluğuna ve tüm genomdaki toplam büyüklüğüne göre minisatellit, mikrosatellit, satellit ve ribozomal DNA (rDNA) dizileri olmak üzere dört grup altında incelenmektedir [30]. Hücre döngüsü boyunca yoğun olarak katlanmış bir kromatin bölgesi olan heterokromatinin büyük bir bölümünü oluşturan sentromerik tekrarlar, en yaygin olarak satellit DNA dizileri ve retrotranspozonları içermektedir [31]. Sentromerik DNA dizilerinin genomdaki bulunma sıklığı ve genomik lokus sayısı türden türe değişebilmektedir. Farklı bitki genomlarındaki sentromerik DNA tekrarların kompozisyonunu belirleyen süreçler hakkında bilgi edinmenin bir yolu, birden fazla türde bulunan tekrarların detaylı bir karakterizasyonu yapılarak filogenetik çerçeve kapsamında analiz etmektir [6, 32]. Yakın zamana kadar, bu tür karakterizasyon çalışmaları, tekrar dizilerinin yüksek oranları, çeşitliliği ve dizi karmaşıklığı nedeniyle daha az oranda yapılmaktaydı. Ancak son yıllarda bitki biyoteknolojisinin gelişmesi üzerine yeni nesil dizileme teknolojileri ve farklı biyoinformatik yaklaşımların entegrasyonu sonucu çok fazla ilerleme kaydedilmiştir [26]. 
Tablo 2. Ökaryotik organizmalardaki sentromerik DNA dizileri

\begin{tabular}{|c|c|c|c|c|c|c|}
\hline & Bitki türü & Aksesyon & $\begin{array}{l}\text { Ardışık } \\
\text { tekrar adı }\end{array}$ & Bulunduğu konum & Dizi uzunluğu (bç) & Referans \\
\hline \multirow{8}{*}{1} & \multirow{5}{*}{$\begin{array}{l}\text { Arabidopsis } \\
\text { thaliana }\end{array}$} & \multirow[t]{5}{*}{ X04323 } & 180-bp & Sentromer & 180 & {$[97]$} \\
\hline & & & family ${ }^{*}$ & & & [59] \\
\hline & & & $\mathrm{pAtMR}^{+}$ & Sentromer & 180 & [98] \\
\hline & & & $\mathrm{pAtHR}^{+}$ & Sentromer & 180 & [98] \\
\hline & & & $\mathrm{pAL1}^{+}$ & Sentromer & & [97] \\
\hline & $\begin{array}{l}\text { Nicotiana } \\
\text { tabaccum }\end{array}$ & \multirow[t]{3}{*}{ X12489 } & HRS60 & & 184 & [99] \\
\hline & Oryza sativa & & $\mathrm{CentO}^{+}$ & Sentromer & 155 & {$[48]$} \\
\hline & Zea mays & & CentC $^{+}$ & Sentromer & 156 & [49] \\
\hline \multirow{20}{*}{2} & Astragalus sinicus & \multirow[t]{7}{*}{ AB649141 } & CentAs ${ }^{*}$ & Sentromer & 20 & {$[50]$} \\
\hline & Lotus corniculatus & & $\mathrm{LjTR}^{+}$ & & 190 & {$[100]$} \\
\hline & $L$. & & $\mathrm{LjTR}^{+}$ & & 237 & \\
\hline & Medicago & & MtR1-Mtr2 & Sentromer & $150-300$ & {$[101]$} \\
\hline & truncatula & & $-\mathrm{Mtr}^{+}$ & Perisentromer & & \\
\hline & \multirow[t]{2}{*}{ Phaseolus vulgaris } & & CentPV1 ${ }^{*}$ & & 110 & {$[32]$} \\
\hline & & & CentPV2* & Sentromer & & {$[32]$} \\
\hline & \multirow[t]{4}{*}{ Pisum sativum } & AF300830 & PisTR-B & Setromer & 50 & {$[102]$} \\
\hline & & & & Subtelomer & & \\
\hline & & AF300839 & PisTR-A & Dağınık & 212 & {$[102]$} \\
\hline & & & TR-12 & & & {$[103]$} \\
\hline & \multirow[t]{4}{*}{ Vicia faba } & & FokI & Dağınık & 59 & \\
\hline & & & $\mathrm{pVf7}$ & Dağınık & 169 & \\
\hline & & & 172 bç & Dağınık & 172 & \\
\hline & & & TIII15 & Dağınık & 58 & \\
\hline & \multirow[t]{5}{*}{ Vigna unguiculata } & Z49817 & $\mathrm{pVuKB} 1^{+}$ & Sentromer & 488 & {$[104]$} \\
\hline & & AJ131983 & $\mathrm{pVuKB} 2^{+}$ & Sentromer & 436 & [104] \\
\hline & & & $455 \mathrm{bp}$ & Sentromer & 455 & {$[105]$} \\
\hline & & LC490941 & $721 \mathrm{bp}$ & Sentromer & 721 & {$[106]$} \\
\hline & & LC490942 & 1600 & Sentromer & 1600 & {$[106]$} \\
\hline & \multirow[t]{7}{*}{ Glycine max } & \multirow[t]{2}{*}{ U 11026} & SB92 ${ }^{+}$ & - & 92 & {$[107]$} \\
\hline & & & STR $120^{+}$ & - & 120 & {$[108]$} \\
\hline & & \multirow[t]{3}{*}{ CL867099 } & STR102+ & Perisentromer & 120 & [109] \\
\hline & & & CentGm- $1^{+}$ & Sentromer & 92 & {$[53]$} \\
\hline & & & CentGm- $2^{+}$ & Sentromer & 94 & {$[53]$} \\
\hline \multirow[t]{5}{*}{3} & & AB536710 & $\begin{array}{l}\text { GmCENT- } \\
1^{*}\end{array}$ & Sentromer & 299 & {$[38]$} \\
\hline & & AB536703 & GmCENT-4* & Sentromer & 431 & {$[38]$} \\
\hline & $\begin{array}{l}\text { Glycine max spp. } \\
\text { soja }\end{array}$ & & CentGm-1 ${ }^{+}$ & - & 92 & {$[53]$} \\
\hline & Glycine latifolia & & CentGm-1 $1^{-}$ & - & 91 & {$[54]$} \\
\hline & Glycine tomentella & & CentGm-1 $1^{-}$ & - & 92 & {$[54]$} \\
\hline
\end{tabular}

${ }^{(*)}$ ChIP temelli, ${ }^{(+)}$klon temelli, ${ }^{(-)}$in siliko temelli çalışmaları ifade etmektedir.

1: Model bitkiler 2: Baklagiller 3: Soya türleri

Tekrarlayan DNA dizileri, genom içerisinde bulunuşları bakımından dağınık tekrarlar ve ardışık tekrarlar olmak üzere iki temel sınıfa ayrılmaktadır. Dağınık tekrarlar olarak bilinen transpozonlar, kodlama dizilerinin yapısı, uzunluğu, kararlılığı ve transpozisyon mekanizmalarına göre kendi içerisinde farklı gruplara ayrılabilmektedir. Ardışık tekrarlar ise, tekrarlayan DNA molekülünün monomer uzunluğuna ve tüm genomdaki toplam büyüklüğüne göre minisatellit, mikrosatellit, satellit ve ribozomal DNA (rDNA) dizileri olmak üzere dört grup altında incelenmektedir [30]. Hücre döngüsü boyunca yoğun olarak katlanmış bir kromatin bölgesi olan heterokromatinin büyük bir bölümünü oluşturan 
sentromerik tekrarlar, en yaygın olarak satellit DNA dizileri ve retrotranspozonları içermektedir [31]. Sentromerik DNA dizilerinin genomdaki bulunma sıklığı ve genomik lokus sayısı türden türe değişebilmektedir. Farklı bitki genomlarındaki sentromerik DNA tekrarların kompozisyonunu belirleyen süreçler hakkında bilgi edinmenin bir yolu, birden fazla türde bulunan tekrarların detaylı bir karakterizasyonu yapılarak filogenetik çerçeve kapsamında analiz etmektir [6, 32]. Yakın zamana kadar, bu tür karakterizasyon çalışmaları, tekrar dizilerinin yüksek oranları, çeşitliliği ve dizi karmaşıklığı nedeniyle daha az oranda yapılmaktaydı. Ancak son y1llarda bitki biyoteknolojisinin gelişmesi üzerine yeni nesil dizileme teknolojileri ve farklı biyoinformatik yaklaşımların entegrasyonu sonucu çok fazla ilerleme kaydedilmiştir [26].

Sentromerik bölgeler için hareketli transpozonlar önemli bir tekrarlayan DNA dizi ailesidir. Transpozonlar, transpozisyon mekanizmasina göre ribonükleik asit (RNA) ara ürünüyle aktarıldığında retrotranspozon, DNA ara ürünüyle aktarıldığında DNA transpozon olarak ifade edilmektedir. Retrotranspozonlar, ters transkriptaz (RT) aktivitesinin varlığına bağlı olarak RNA ara ürününün DNA dizisine dönüştürülüp tekrar genoma dahil etmesi ile yayılım göstermektedir. Retrotranspozonlar DNA dizilerinin yapılarına bağlı olarak LTR (long terminal repeat), LINE (non-LTR retrotransposons or long interspersed element) ve SINE (short interspersed element) olmak üzere üç sınıfta tanımlanmaktadır [33]. Bitki genomunun büyük bir oranını oluşturan LTR retroelementinin sinıflandırılmasıyla meydana gelen Ty3/gypsy ve Ty3/copia aileleri genomda en çok bulunan dağınık hareketli elementlerdir. Literatür incelendiğinde, Pisum sativum tüm genomundaki Ty1/copia elementleri, Ty3/gypsy elementleri ile karşılaştırıldığında genomun çok daha küçük bir bölümünü kapsamaktadır [34]. Bununla birlikte Ty1/copia elementlerinin daha fazla sayıda farklı aileden meydana geldiği saptanmıştır [34]. Retrotranspozonlar tüm genoma yayılım gösterdiği gibi sadece sentromere spesifik olarak da bulunabilmektedir (Şekil 1C). Sentromerik retrotranspozon (CR) dizileri sentromerik ardışık tekrarlara kıyasla daha fazla korunmuş yapıdadır. Oryza sativa'da CRR [35], Zea mays'ta CRM [36], Brassica rapa'da CRB [37], Glycine max'ta GmCR [38] türler arasındaki korunmuş sentromerik retrotranspozonlara örnektir. Bu türlerdeki sentromerik yapının karakterizasyonu sonucu; sentromerik ardışı tekrarların çeşitli retrotranspozonlar tarafinca kesintiye uğradığı ortaya çıkartılmıştır (Şekil 1C). Örneğin Arabidopsis thaliana 180 baz çiftlik tekrar ailelerinin bazen Athila retrotranspozonları tarafından kesintiye uğrayarak sentromer dışında perisentromerik bölgelerde de birikebildiği yapılan çalışmalar aracılığıyla ispatlanmıştır [39].
Bir diğer sentromerik DNA dizisi olan satellit DNA dizileri, sentromerde en sık karşılaşılan ardışık tekrardır. Adenin-Timin (AT) açısından zengin bir tekrar birimine sahip olan satellit DNA dizilerinin monomer uzunluğu bitki ve hayvanların çoğunluğunda 150-400 bç olarak değişmektedir [40, 41]. Tekrarlayan DNA miktarı, farklı AT/GC içeriği nedeniyle gradient yoğunluk santrifüjünde uydu (satellit) bantlar oluşturmuştur ve daha sonra bu bantlar izole edilerek in situ hibridizasyonla kromozom üzerindeki konumları belirlenmiştir [42, 43].

Satellit DNA aileleri, kromozomda meydana gelen eşit olmayan parça değişimi (unequal exchange), yuvarlanan halka çoğalması (rolling circle amplification), replikasyon kayması ve mutasyon gibi moleküler mekanizmalar sonucu ortaya çıkmaktadır $[44,45]$. Bu mekanizmalar sayesinde kompleks ökaryotik genomların yaklaşık \% 90'ını kapsayarak genomun temel bir bileşeni haline gelmiştir [41, 46]. Satellit DNA aileleri, bazen genom boyunca dağılmış bir özellik gösterirken bazen de kromozom üzerinde sentromer spesifik bir bölgeye lokalize olabilmektedir [47] (Şekil 1C). Yaptığımız çalışma kapsamında, sentromerik satellit DNA dizilerinin bitkilerdeki örnekleri model organizmalarda, baklagillerde ve önemli bir baklagil ailesi olan Glycine türleri kapsamında taranmıştır (Tablo 2). Model organizmalardan, Arabidopsis thaliana 180 baz çiftlik sentromerik tekrar1 [39], Oryza sativa CentO [48], Zea mays CentC [49] satellit tekrarlarını içermektedir. Baklagillerden Astragalus sinicus CentAs [50] ve Glycine cinsine ait Glycine max birbirinden bağımsız iki farklı GmCent-1 ve GmCent-4 [38] satellit tekrar ailelerini içermektedir. Tekrarlayan DNA dizilerinin tür içi ve türler arasındaki karşılaştırılması sonucu, evrimi ve nasıl çoğaldığı hakkında kapsamlı bilgi edinilebilmektedir. Bazı tekrarlayan DNA dizileri türler arasında yüksek derecede korunurken, bazı durumlarda da hızlı değişim göstermesi sebebiyle yakın akraba türleri arasında bile farklılıklar gösterebilmektedir. Örneğin, çeltikte (Oryza sativa) 155-bç'lik sentromerik satellit tekrar olan CentO, birkaç yabani çeltik türünde mevcut değildir [51]. Bu yabani türlerden biri olan Oryza brachyantha, CentO ile homoloji göstermeyen CentO-F olarak adlandırılan 154-bç'lik farklı bir sentromerik satellit tekrar dizisini içermektedir. Bununla birlikte, CentO tekrarı, çeltikten daha uzak ilişkili olan mısırdaki sentromerik satellit tekrarı CentC ile önemli dizi homolojisi göstermektedir $[51,52]$. Yağ ve protein içeriği bakımından önemli bir baklagil türü olan soyada (Glycine max) saptanan GmCent-1 sentromerik satellit tekrar ailesinin varlığ tüm genomu dizilenen bazı yabani soya türlerinde taranmıştır [38, 53]. Glycine soja GmCent-1 tekrar ailesinin dizilerini içerirken, $G$. tomentella ve $G$. latifolia yabani türleri de GmCent-1 satellit tekrarını genomlarında içerdiği belirlenmiştir [54]. Ne var ki, diğer sentromerik tekrar olan GmCent-4 diğer türlerde ayrıntılı olarak henüz araştırılmamıştır. Bunun gibi 
farklı sentromerik ardışık tekrarlayan DNA dizilerinin, tür içinde ve türler arasında yatay gen transferi, poliploidizasyon ve benzeri mekanizmalarla açıklanabileceği öngörülmektedir. Korunmuş tekrarlayan DNA dizilerinin bu özelliğinden faydalanarak türler arasındaki evrimsel ve filogenetik ilişkiler belirlenebilmektedir [43].
A
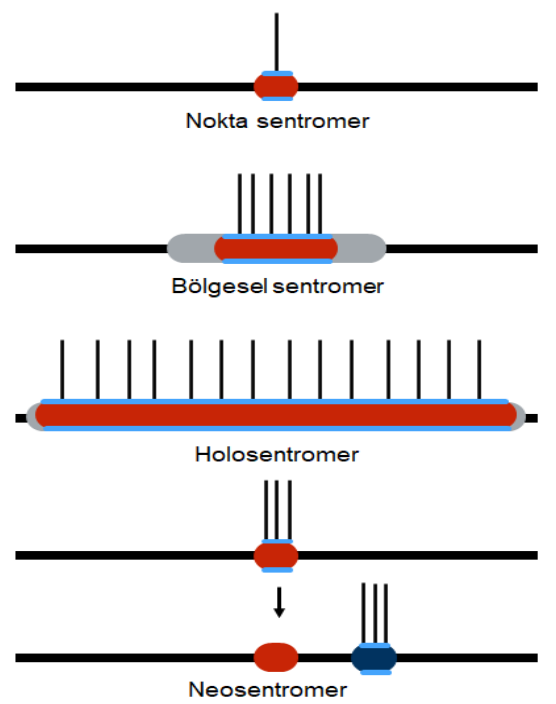

B

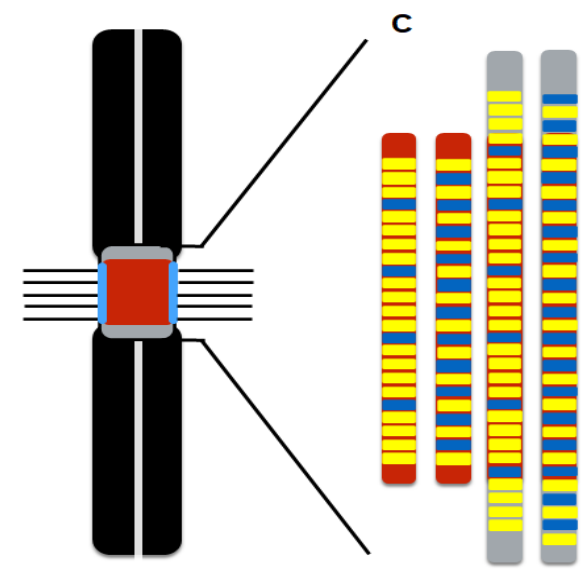

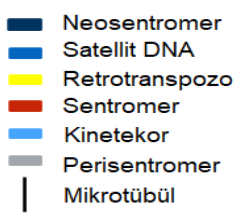

Şekil 1. Ökaryotik organizmaların kromozomlarında görülen farklı sentromer yapısı ve sentromer DNA organizasyon tipleri. A. Nokta sentromer, bölgesel sentromer, holosentromer ve neosentromer yapıs1. B. Tipik bir ökaryotik metafaz kromozomu. C. Sentromerik ve perisentromerik alanlardaki satellit DNA ve retrotranspozon tekrarlayan elementlerin olası dağılımları.

Farklı türlerdeki sentromerik tekrarlayan DNA aileleri sentromer-kinetokor kompleksinin anahtar bileşeni olarak rol oynamaktadır. Tekrarlayan DNA dizileri kinetokor proteinlerinin esas bileşeni olmak dişında, kromozom hareketi ve eşleșmesi, sentromerik yoğunlaşma, kromozom rekombinasyonu, kardeş kromatid eşleşmesi, mitotik iğ ile kromozomal bağlanma, kromozom düzenlemesi, kromatin proteinlerinin etkileşimi, histon katlanması, kromozom yapısının belirlenmesi, karyotipik evrim, gen ekspresyonunun düzenlenmesi, çevresel uyaranlara ve fizyolojik değişikliklere genom cevabının düzenlenmesi gibi çok fazla süreçte işlevseldir [55, 56]. $\mathrm{Bu}$ nedenle türlerin evrim mekanizmalarının temelini oluşturmaktadır. Türe özgü satellit DNA oluşumu, türlerin hızlı ve güvenilir bir şekilde tanımlanmasını sağlar. Ancak buna rağmen bazen taksonomi içerisinde bazı tekrarlayan DNA dizilerinin muhafaza edilebildiği de belirtilmektedir [41]. Grewal ve Elgin [28], yaptığ çalışmada heterokromatin yapısının oluşumu ve sürdürülmesi açısından satellit DNA'nın transkripsiyonunu ve bunun heterokromatin üzerindeki etkisini devam ettirdiğini tespit etmiştir. Tekrarlayan DNA dizileri ayrıca nükleoprotein komplekslerinin oluşumu için yardımcı moleküler etkileşimlerde rol oynayarak sentromer yap1 ve fonksiyonunun korunmasını sağlamaktadır [57]. Ayrıca tekrarlayan DNA dizilerinin transpozitif olması durumunda yeni genler oluşturabileceği de öngörülmektedir [41]. Yapılan sitogenetik ve moleküler çalışmalar kapsamında satellit DNA dizilerinin işlevleri net olarak anlaşılmaya çalışılmıştır.
Genom yapısının daha iyi aydınlatılması için yüksek verimli DNA dizileme teknolojileri ile tüm genom dizilenmesinin yapılması gerekmektedir. Fakat tekrarlayan DNA dizilerinin çok uzun olması ve yüksek AT/GC içeriğinden dolayı dizileme ve karakterizasyonda sıkıntılar yaşanmaktadır. Tekrar dizilerinden kaynaklı genomun karanlık yüzünün aydınlatılması için bilim adamları günümüze kadar çok fazla yöntem geliştirilmiştir ve hâlâ yeni tekniklerin arayışı içerisindedir. Sentromerik tekrar dizileri, ilk olarak gradient yoğunluk santrifüjlemesi yapılarak tespit edilmesinin ardından 1970'li yillarda restriksiyon enzim teknolojisinin gelişmesiyle, genomik DNA, restriksiyon enzimlerle kesilip agaroz jel elektroforezinde fragmentasyonu yapilarak satellit DNA motiflerinin tanımlanması sağlanmıştır. Ayrıca koloni filtre hibridizasyonu, spesifik primerlerle amplifikasyon, gibi farklı yöntemler kullanılarak genomik DNA dizileri içerisindeki tekrarlar kolaylıkla tespit edilebilmektedir [58]. Günümüzde ise, membran sistemi kullanılarak Dot blot, Southern blot gibi teknikler ile DNA-DNA in situ hibridizasyonu yapılarak tekrar dizilerin tespiti sağlanmaktadır. Son zamanlarda sentromerik tekrar dizilerinin tespiti için protein-DNA etkileşimine dayanan ChIP (Kromatin immünopresipitasyon) tekniğinden faydalanılmaktadır. ChIP tekniğiyle sentromerik CENH3 proteinlerine karşı antikor geliştirilerek sentromerik DNA dizileri kolaylıkla tanımlanabilmektedir [59]. Bunlar dışında, tüm genom veya kısmi genom dizisi bilinen türlerdeki tekrarların tespiti için klon temelli analizler ve in siliko analizler yapılmaktadır (Tablo 2). In siliko analizlerde 
sentromerik DNA dizileri, WGS (Whole Genome Shoutgun) ve NGS (Next Generation Sequencing) dizileme teknolojileriyle birlikte çeşitli biyoinformatik yaklaşımların entegrasyonu sonucu kolaylıkla saptanabilmektedir. Biyoinformatik analizde sık kullanılan grafik tabanlı dizi kümeleme araçları olan RepeatExplorer [60], RepeatAnalyzer, RepeatFinder, Recon gibi farklı yazılımlar genom dizisi verilerindeki yüksek ve orta kopya tekrarları tanımlamak için değerli veriler sağlamaktadır [43]. Sonuç olarak sürekli gelişmekte olan ileri teknolojiler aracılığıyla genomun bilinmeyen yüzü olan sentromer ve etkileşimde bulunduğu protein dizilerinin karakterizasyonunda bir adım öne geçilmesi bilim insanlarınca hedeflenmektedir.

\subsection{Sentromer proteinleri}

Sentromer proteinleri, ökaryotlarda sentromerin tanımlanmasında ve sentromerik fonksiyonun gerçekleştirilmesinde yardımcı öğelerdir. Bu proteinler ilk olarak Skleroderma CREST semptomları bulunan hastanın serumundan izole ederek tanımlanmıştır. Serum örneğinde 3 farklı uzunlukta SENtromer Proteini (CENP: CENtromere Protein) tespit edilmiştir. Bu proteinler CENP-A (17 kDA), CENP-B (80 kDA) ve CENP-C (140 kDA) şeklinde adlandırılan kinetokor bağlanma proteinleridir. Otoimmün hastalarda bu proteinleri tanıyan anti-sentromer antikorları tespit edilerek bu antikorların mitotik hücrelerde hastalığın oluşmasında dolaylı yoldan etkili olduğu anlaşılmıştır [61]. İlk defa CENP-A tanımlandıktan sonra HeLa tümör hücrelerinde CENP-A proteinin histon ve nükleozomlarla bağlantılı olduğu saptanmıştır [62]. Ardından yapılan birçok çalışmada CENP-A proteininin insan sentromerleri dışında mantar, hayvan ve bitki sentromerlerinde de homologları tespit edilmiştir. Benzer şekilde CENP-C proteinin karşılığ da belirtilen organizmalarda bulunurken, CENP-B proteinin karşılığı bitkilerde bulunamamıştır [6].

Kinetokor, kardeş kromatitleri doğru bir şekilde bir arada tutan ve iğ ipliklerinin sentromere bağlanmasından sorumlu olan temel sentromerik bir bileşendir. $\mathrm{Bu}$ yapının iç ve diş yüzeyine sentromer proteinleri bağlanarak sentromer işlevini ortaya çıkarmaktadırlar $[63,64]$. CENP-A proteini gibi iç yüzeydeki kinetokor proteinleri hem sentromerin karakterizasyonunda hem de kromozomların doğru ayrışmasında görev alırken, dış yüzeydeki kinetokor proteinleri sadece kromozomların doğru ayrışmasında görev almaktadır [64, 65].

CENP-A proteinin homoloğu bitkilerde genellikle farklı uzunluklardaki CENH3 proteinleri şeklinde karakterize edilmiştir. Model bitkiler kapsamında Arabidopsis thaliana'da 176 aa uzunluğunda HTR12 [4], Zea mays'da 157 aa uzunluğunda ZmCENH3 [36], Oryza sativa'da 164 aa uzunluğunda OsCENH3 [66] karakterize edilmiştir. Baklagiller kapsamında ise Glycine max'da 158 aa uzunluğunda GmCENH3 [38], Lotus japonicus 159 aa uzunluğunda LjCENH3 [67] ve
Onobrychis viciifolia OvCENH3 [68] proteinleri farkl1 CENH3 homoloğu örnekleri arasındadır. CENH3 proteini kinetokoru oluşturan protein kompleksinin temel bir parçasıdır. Sentromer DNA'sı CENH3 proteini ve diğer histon proteinleri etrafinda paketlenerek sentromerik nükleozomları oluşturmaktadır. Nükleozom çekirdeğini oluşturan histonlardan biri olan standart (kanonikal) histon H3 sentromerde fonksiyonel olarak farklılaşarak yerini histon varyantı olan CENH3 proteinine bırakmaktadır [69]. Bu protein evrimsel süreçte dizi bilgisi bakımından farklılık gösterse de sentromerin karakterize edilmesi sürecinde işlevini kalıcı tutmaktadır [4, 70]. İşlevsel olarak sentromerin belirlenmesi sırasında epigenetik işaretleyici olarak kullanılarak sentromer hakkında bilginin artmasını sağlamaktadır [6].

Başka bir sentromer proteini olan CENP-C, CENH3 gibi kinetokorun iç yüzeyinde bulunan ve kardeş kromatitlerin doğru şekilde ayrışmasından sorumlu sentromerik DNA ile ilişkili bir proteinidir [65, 71]. Bitkilerden ilk olarak misir sentromerinde tespit edilen CENP-C proteini, Arabidopsis gibi model bir bitki üzerinde de bulunmasına öncülük etmiştir [71, 72]. Bu proteinin dizilerinin sadece bitkilerde C-terminal bölgesinde korunduğunu saptanmıştır [72]. Sentromer proteinlerin bitkiler üzerinde tanımlanması epigenetik gibi nedeni tam olarak bilinmeyen mekanizmaların çözümlenmesinde yardımcı olacaktır.

\subsection{Sentromerlerin epigenetik oluşumu}

Kromozom ayrışmasında temel bir yapı olan fonksiyonel sentromer, mayoz ve mitoz hücre bölünmelerinde sırasıyla, homolog kromozomların zıt kutuplara çekilmesini ve kardeş kromatidlerin uygun şekilde ayrışmasını sağlamaktadır. Ayrıca satellit DNA dizileri ve retrotranspozon sentromerik DNA dizilerinin kontrolü de genom bütünlüğünü bozmayacak şekilde sentromer tarafindan sağlanmaktadır [73, 74]. Bunun gibi kritik rollere rağmen, bitkilerde fonksiyonel bir sentromerin nasil karakterize edildiğinin kesin bir tanımını yapmak hala zordur. Şu ana kadar elde edilen mevcut veriler sentromer oluşumunun epigenetik mekanizmalarla kontrol edildiğini işaret etmektedir. Peki bu kadar karmaşık ve bilinmeyen cevaplarla dolu olan epigenetik mekanizmayı yöneten unsurlar nelerdir? DNA dizisinde herhangi değişikliğe sebep olmadan gen ifadesini, kromozom yapısını ve fonksiyonunu değiştiren, genom bütünlüğünü sağlayan mekanizmaların hepsi epigenetik terimi altında toplanmaktadır [31]. Genom bütünlüğü DNA metilasyonu, kromatin, post-translasyonel histon ve RNA aracılı modifikasyonlar ile sağlanmaktadır. Bitki sentromerlerinin epigenetik oluşumu, önceleri CENH3 proteini ve siRNA'lar incelenerek anlaşılmaya çalışılmıştır. Son zamanlarda ise, disentrik kromozomlar üzerindeki sentromerlerden birisinin inaktivasyonu ve neosentromer oluşumu incelenerek yeni mekanizmalar geliştirilmiştir $[6,12]$. 
Kromozom üzerindeki post-translasyonel modifikasyonların en iyi anlaşıldığ epigenetik işaret histon $\mathrm{H} 3$ proteinleridir. Aktif sentromerlerde ise bu modifikasyonlar $\mathrm{CENH3}$ proteinin varlığıyla tespit edilebilmektedir [4, 75]. CENH3 proteininin özellikle $\mathrm{N}$ terminal bölgesindeki kovalent modifikasyonlarının kromatin durumunu ve gen transkripsiyonunu etkilediği bilinmektedir. CATD (histon katlanma alanı) bölgesi ise sentromere $\mathrm{CENH} 3$ proteini yüklenmesinden sorumlu olup çeşitli histon modifikasyonları ile bu kontrolleri sağlamaktadır [76]. Zhang vd., [48] misir ZmCENH3 proteininde pS50 fosforilasyonunu tespit etmelerinin ardından Demidov vd., [77] tarafindan Arabidopsis'te çiçek gelişiminin kontrolünden sorumlu Aurora3'ün HTR12 pS65 proteinini fosforile ettiği saptanmıştır. Ancak baklagillerde dahil olmak üzere hala CENH3 posttranslasyonel modifikasyonları belirlenemeyen çok fazla bitki türü bulunmaktadır. $\mathrm{Bu}$ eksikliği giderebilmek için CENH3 proteininin etkileşimde bulunduğu diğer proteinler, sentromerik ardişık tekrarlar ve retrotranspozonlarda meydana gelen metilasyonlarının anlaşılması gerekmektedir [57]. Bu sentromerik DNA dizilerinde saptanan epigenetik modifikasyonlar (DNA metilasyonu gibi) ilerde olası post-translasyonel modifikasyon analizlerininde temelini oluşturacaktır.

Sentromerik tekrar dizilerindeki DNA metilasyonları farklı teknikler kullanılarak başta model organizmalar olmak üzere birçok bitki türünde tespit edilmiştir. Zhang vd., [78], Arabidopsis thaliana ve Zea mays model bitkilerinde sentromerik ve perisentromerik bölgelerde bulunan 178 bç'lik tekrar dizisinin her iki türde de sentromerik bölgede, perisentromerik bölgelere kıyasla daha fazla hipometile edildiği tespit edilmiştir. Ayrıca, sentromerik bölgelerde DNA hipometilasyonunun düşük bir $\mathrm{H} 3 \mathrm{~K} 9 \mathrm{me} 2$ seviyesi ile ilişkili olduğu gösterilmiştir. Oryza sativa'da bulunan CentO tekrarları Arabidopsis ve misırdaki sentromerik satellitlerde olduğu gibi hipometilasyon göstermiştir. Ayrıca ilgili bazı sentromerlerdeki sitozin metilasyonlarının haritalanması sonucu CENH3 ile ilişkili domainlerin, H3 domainine kıyasla yüksek DNA metilasyon seviyesi gösterdiği ortaya çıkmıştır [79]. Wu vd., [80], çeltikte dört farklı ökromatik histon modifikasyonunu taramıştır ve sonucunda sadece bir ökromatik modifikasyonun sentromerik $\mathrm{H} 3$ domainde gömülü kopyalanmış sentromerik dizilerle ilişkili olduğunu ortaya koymuştur.

Barbara McClintock tarafindan 1956 yılında ilk defa misırda keşfedilen retrotranspozonlar, gen aktivasyonu, inaktivasyonu, genom bütünlüğü, evrimsel seçilim, replikasyon ve rekombinasyon gibi farklı rolleri üstlenmektedir [81]. Ayrıca genomda mutasyonlar oluşturarak genetik varyasyona ve türleşmeye önemli katkılar sağlamaktadır. Bu yüzden günümüzde yapılan ıslah çalışmalarının hedefi halindedir. Etkin ve çok fonksiyonlu olan hareketli DNA elementlerinin metilasyonlarının belirlenmesi tüm bu çalışmaların önünü açacaktır. Sonuç olarak, sentromerik tekrar dizilerinde meydana gelen epigenetik mekanizmalar, CENH3 proteinin sentromere bağlanmasını ve kromozom yapısının korunmasını sağlamaktadır. Ayrıca bu dizilerdeki DNA metilasyonları, sentromer ile perisentromerik kromatin bölgelerinin ayırt edilmesinden ve kinetokor oluşumundan sorumludur.

Neosentromerler, kromozomdaki atasal sentromer ile ilişkili olmayan bir genomik bölgeden gelen epigenetik bir oluşumdur. Büyük ve karmaşık genomları olan ökaryotlarda kromozomlar üzerinde çeşitli bölgelerde aktive edilebilmekle birlikte genellikle gen yoğunluğu az heterokromatik bölgelerde işlevseldir. $\mathrm{Bu}$ nedenle neosentromer, oluştuğu konumdaki genleri baskılayabilir özelliktedir [26, 74]. Ayrıca genom düzenlenmesinde de aktif olarak rol alan sentromerik bir işaret olarak da düşünülmektedir. Olgun sentromerlerin neosentromerlerden evrimleştiği fikrini destekleyen kanıtlar günümüzde hala süregelen yoğun çalışmalar sayesinde aktifliğini korumaktadır.

İlk olarak mısırda keşfedilen sentromere spesifik kodlanmış RNA'lar, sentromer için potansiyel epigenetik işaretlerden bir diğeridir. Bu küçük RNA'lar (siRNA; yaklaşık 40-75 nt) kinetokorun temelini oluşturan sentromer spesifik nükleozomların yüklenmesinin, sentromerik transkripsiyona bağlanabileceğine dair kanıtlar sunmaktadır. Sentromerik transkriptler, sentromer lokalizasyonu için CENH3 gibi kinetokor proteinleri tarafindan bağlanır. Bazı transkribe olmayan RNA'lar da gen ekspresyonunu ve kinetokor bağlanmasında işlevseldir [82]. Misır, çeltik ve Arabidopsis'te yapılan çalışmalarda kinetokor ile ilişkili RNA dizileri CHIP yöntemiyle belirlenmeye çalışılmıştır. Sentromerik satellit tekrar ve retrotranspozonlarla etkileşimde olan çok sayıda siRNA transkriptleri elde edilmiştir [75, 83, 84, 85]. siRNA'lar, metilasyon için spesifik DNA dizilerini hedefleyerek bitkilerde heterokromatin oluşumunu teşvik edebilir, bu nedenle transkripte edilmiş sentromerik diziler, kinetokor oluşumuna uygun bir kromatin ortamı sağlamada hayati bir rol oynamaktadır [74]. Sonuç olarak siRNA aktif bir sentromer yapısının organizasyonu için önemli bir epigenetik işarettir.

Epigenetik mekanizmalar haricinde DNA dizisinin fonksiyonel bir sentromer oluşturulmasında rol oynadığına dair bir takım kanıtlar bulunmuştur. Yakın zamanda mısır ve buğdayda B kromozomu türevlerini içeren iki bitkinin melezlenmesi sonucu büyük ve küçük B sentromerlere sahip disentrik kromozomların varlığ 1 tespit edilmiştir. $\mathrm{Bu}$ disentrik kromozomlar kararlı yapıdadır ve bir sentromer aktifken diğer sentromer inaktif formda bulunmaktadır. Bu tür diziler hem aktif hem de inaktif sentromerler için yapılarını koruduklarından dolayı, sentromer aktivitesinin DNA dizisinden bağımsız bir epigenetik bileşenle sağlandığ 1 
sonucuna varılmıştır. İnaktif B sentromeri her nesilde kararlı olarak iletilir ve inaktiviteyi korur ancak bazı durumlarda, aktif olmayan sentromerler, çeşitli modifikasyonlarla yeniden düzenlenerek sentromer fonksiyonunu geri kazanabilmektedir [12, 86]. Bitki sentromer fonksiyonu ve yeniden düzenlenmesinde dinamik ve hızla değişebilen bir takım farklı epigenetik mekanizmalar bulunmaktadır. Epigenetik mekanizmaların anlaşılması ilerde yapılabilecek sentromer temelli modifikasyonlar ile elde edilebilecek haploid bitkilerin temellerini oluşturacaktır.

\subsection{Sentromer modifikasyonlarında gelecek beklentiler}

Haploid üretimi, birçok mahsul bitki türünün üreme sürecini hızlandıran ve homozigotluğu sağlayan temel süreçlerden biridir. Ayrıca, gerçek 1slah hatlarını elde etmek için geleneksel sslah ile yıllarca süren kendileme veya geriye melezleme ihtiyacı olmadan, tüm genom replikasyonu yoluyla tek bir nesilde tüm lokuslarda elde edilebilmesini sağlayan güçlü bir sslah yöntemidir. Geleneksel 1slaha kiyasla hem zaman hem de kaynaklarda önemli bir tasarruf sağlamaktadır. Haploidler in vitro veya in vivo elde edilebilir, ancak birçok tür ve genotipte bu işlemler süresince aşılması gereken birtakım zorluklar vardır [87, 88, 89, 112]. Mevcut haploid teknolojilerinde uygulanabilirlikteki eksiklikler nedeniyle, bitki yetiştiricileri ve bilim insanları yeni teknikler geliştirerek farklı haploidizasyon prensipleri arayışına girmiştir. Sentromer mühendisliği ile haploid bitkilerin üretimi, bu zorlukların üstesinden gelmek için umut verici bir yöntemdir. $\mathrm{Bu}$ yaklaşım bitki 1slahçıları tarafından büyük bir heyecanla karşılanmış olmasına rağmen şu anda herhangi bir üründe sentromer mühendisliği yoluyla geliştirilen haploid bitki örneği bulunmamakla birlikte çalışmalar hala devam etmektedir [73, 90, 91, 112].

Sentromer mühendisliği kapsamında genom eliminasyonuna dayanan tür içi veya türler arası melezleme yoluyla haploid bitki elde edilmeye çalışılmaktadır [92]. Sentromerin karakterize edilmesinde sıç̧a kullanılan CENH3 haploid bitki eldesi için hedef bir proteindir. Ravi ve Chan [73] doğal bir tetraploid Arabidopsis'i diploid bir yapıya dönüştürmek için $\mathrm{CENH3}$ proteinini mutasyona uğratarak fonksiyonunu spesifik olarak değiştiren yeni bir yaklaşımın temelini atmıştır. Elde edilen mutant kimerik CENH3 proteinleri "GFP-CENH3" ve "GFPtailswap" olduğu durumlarda bitki için ölümcül olmamıştır ve genom eliminasyonu ile haploid hat elde edilebilmiştir. Bu öncü çalışma sayesinde, sentromerler ve CenH3 geni artı sadece temel öneme sahip epigenetik bir işaret değil, aynı zamanda önemli tarımsal uygulamalar için potansiyel bir alan olarak da görülmeye başlamıştır [93]. Kuppu vd., [91], A. thaliana HTR12 proteinindeki CATD bölgelerinde tek bir amino asitte değişiklik yaparak mutant yeni hatlar oluşturmuştur. Bu hatların birçoğu, kendine döllenmede verimli iken, yabani türlerle melezlendiğinde benzersiz haploid bitkiler üretmiştir. Yapılan her iki çalışmadan yola çıkarak CENH3'nin mutasyona uğramış olan CATD bölgesi yüksek derecede evrimsel olarak korunmuştur ve haploid teknolojisinin çeşitli bitki türlerinde uygulanması için umut verici bir firsat sunmaktadır. Kelliher vd [94], misırdaki CENH3 kaynaklı haploid ıslah hatlarını rapor ettiği çalışmada, CENH3 proteini RNAi teknolojisi ve transpozon yerleştirilmesi ile susturulmuştur. Elde edilen mutant CENH3, bu tür mısır hatlarını üretebilmek için in vivo haploid indüksiyonunda kullanılmıştır. Haploidizasyon çalışmaları sonucu CENH3:RNAi hatlarının diğer hatlara kıyasla daha az haploid ürün verdiği tespit edilmiştir. Son olarak, CRISPR-Cas9 teknolojisi ile Arabidopsis thaliana CENH3 proteininde delesyonlar oluşturarak güçlü haploid hatlar ortaya çıkartılmıştır $[91,95]$.

Sonuç olarak kısa sürede verimli ve homozigot haploid hatlar üretebilmek için sentromer modifikasyonuna dayalı teknolojiler dikkat çekmeye başlamıştır. Tüm canlılar için kalıtımın önemli parçası olan sentromer haploidi ve ıslah çalışmalarında önemli bir yere sahiptir. Bitkilerde CENH3 proteini ile yapılan temel çalışmalar sayesinde gelecekte yeni haploid 1slah hatları geliştirme potansiyeli vardır.

\section{SONUÇ}

Sentromer, hücre bölünmesi esnasında mikrotübüller aracılığıyla kromozomların yeni hücrelere eşit dağılımını sağlayan bir kompleks bir yapıdır [26]. Sentromer, tüm ökaryotlarda fonksiyonel bakımdan korunmuşluk gösteririrken kromozom üzerinde bulundukları konum, yapı ve oluşum mekanizmaları bakımından farklılıklar gösterebilmektedir. Sentromerik farklılıklar, evrimsel süreçte ökaryotik organizmaların birbirlerinden ayırt edilmesine, türleşmeye ve yeni tip sentromerlerin gelişmesine öncülük edecektir. Tek bir sentromer tipi yerine farklı sentromer tiplerinin bulunması tek taraflı bir bakış açısı yerine sentromer biyolojisi ve evrimini çok yönlü anlamaya ve keşfetmeye yardımcı olacaktır [96]. Sentromer biyolojisi tüm ökaryotlarda olduğu gibi bitki sentromerleri özelinde de incelemeler yaparak bitki için sentromerik yapının önemini anlamamıza öncelik etmektedir. $\mathrm{Bu}$ çalışma kapsamında öncelikli olarak model bitkiler ve baklagiller sentromerleri üzerinden temel tanımlamalar yapılacaktır. Ayrica tarihsel perspektiften yola çıkarak farklı bitki türlerinden elde edilen güncel yapısal özelliklerin incelendiği çalışmaları entegre eden moleküler kompleks bir yapı ortaya konulacaktır.

Kompleks bitki sentromerin oluşumu ve korunmasına katkıda bulunan esas elementler sentromerik DNA dizileri ve sentromerik proteinlerdir. Önceleri çöp DNA olarak adlandırılan sentromerik tekrar dizilerinin aslında sentromer üzerinde bulunan sitoplazmik, hücresel ve gelişimsel gibi önemli farklı fonksiyonları 
organizmalardaki önemini gözler önüne sermektedir. Sentromerik tekrar dizileri her ne kadar organizma için çok önemli fonksiyonları olsa da dizilenmesi sırasında dizilerin doğru olarak birleştirilememesi, fiziksel haritaların oluşturulamaması gibi nedenlerden dolayı bitkilerdeki sentromer uzunluğu tam olarak belirlenememiştir ve bitki sentromer evrimi yeteri kadar çözümlenememiştir [24]. Bu nedenle sentromer hala çözümlenmeye ihtiyaç duyan sorularla doludur. Sentromerin tanımlanmasında etken diğer bir fenomen sentromer proteinleridir. Sentromerik tekrar dizileriyle etkileşimde olan sentromerik $\mathrm{CENH} 3$ proteini bu evrimsel sorunun çözümlenmesine katkı sağlayacaktır. CENH3 proteini, kromozom üzerindeki posttranslasyonel modifikasyonların en iyi anlaşıldığ epigenetik işaret olarak bilinmektedir. CENH3 post translasyonel modifikasyonlar öncelikle model bitkilerde taranmış olup baklagiller kapsamında henüz yapılmış bir çalışma bulunmamaktadır. Bu çalışma çerçevesinde bitki sentromerindeki epigenetik ve genetik bilimleri arasındaki çözümlenmiş mekanizmalar ve bu mekanizmaların işlevleri belirlenebilecektir.

Gelecekte bitki sentromerinin tanımlanmasında önemli olan CENH3 proteini üzerinden sentromer mühendisliği aracılığıyla bitki ıslahının en temel sorunu olan zaman problemi çözümlenerek kısa sürede homozigot saf haploid hatlar oluşturulabilecektir. Sentromer mühendisliği aracılığı ile saf haploid hatlar oluşturulmasına yardımcı diğer bir yapı ise çoklu gen kümelerinin eş zamanlı hücreye transfer edilmesi için mini kromozomların (yapay kromozomlar) vektör olarak kullanılmasına dayanmaktadır. Günümüzde henüz bu teknoloji ile yapay bitki kromozomlarını bir araya getiren başarılı bir sonuç sağlanamamıştır $[6,74]$. Ancak CRISPR, RNAi, TILLING gibi farklı yenilikçi yöntemlerle sentromer hedefli ıslah çalışmaları hızlı bir şekilde çalışmaya devam etmektedir.

\section{TEŞEKKÜR}

$\mathrm{Bu}$ çalışma TÜBİTAK (1180670 ve 118Z589) ve COST CA16212 - INDEPTH projeleri tarafindan desteklenmektedir. Yazarlar (HY, BŞY ve SDKÖ) YÖK 100/2000 Sürdürülebilir Tarım ve Bitki Biyoteknolojisi programı tarafından desteklenmektedir. Bitki Kromozom Laboratuvarındaki çalışmalarımız Ayhan Şahenk Vakfı tarafindan desteklenmektedir. Makale değerlendirmesi esnasında kıymetli katkılarından dolayı hakemlere teşekkür ederiz.

\section{KAYNAKLAR}

[1] Mellone, B. G. (2009). Structural and temporal regulation of centromeric chromatin. Biochem Cell Biol, 87(1), 255-264. https://doi.org/10.1139/O08-121

[2] Santos, A. P., Gaudin, V., Mozgová, I., Pontvianne, F., Schubert, D., Tek, A. L., Dvořáčková, M., Liu, C., Fransz, P., Rosa, S., \& Farrona, S. (2020). Tidying-up the plant nuclear space: Domains, functions, and dynamics. J Exp Bot,
71(17), 5160-5178.

https://doi.org/10.1093/jxb/eraa282

[3] Henikoff, S., Ahmad, K., \& Malik, H. S. (2001). The Centromere Paradox: Stable Inheritance with Rapidly Evolving DNA. Science, 293(5532), 1098-1102. https://doi.org/10.1126/science.1062939

[4] Talbert, P. B., Masuelli, R., Tyagi, A. P., Comai, L., \& Henikoff, S. (2002). Centromeric Localization and Adaptive Evolution of an Arabidopsis Histone H3 Variant. The Plant Cell, 14(5), 1053-1066. https://doi.org/10.1105/tpc.010425

[5] Fukagawa, T., \& Earnshaw, W. C. (2014). The Centromere: Chromatin Foundation for the Kinetochore Machinery. Dev Cell, 30(5), 496508. https://doi.org/10.1016/j.devcel.2014.08.016

[6] Jiang ve Birchler. (2013). Plant Centromere Biology (1. bs). John Wiley \& Sons, Ltd. https://doi.org/10.1002/9781118525715

[7] Robertis, D. (1987). Cell and molecular biology. 8th Edition. https://www.osti.gov/biblio/6157496

[8] Bickmore, W. A. (2001). Karyotype Analysis and Chromosome Banding. eLS. https://doi.org/10.1038/npg.els.0001160

[9] Rice, S. (1998). Endless Forms: Species and Speciation. Oxford University Press.

[10] Schubert, I., \& Lysak, M. A. (2011). Interpretation of karyotype evolution should consider chromosome structural constraints. Trends in Genetics, 27(6), 207-216. https://doi.org/10.1016/j.tig.2011.03.004

[11] Doyle, S. R., Tracey, A., Laing, R., Holroyd, N., Bartley, D., Bazant, W., Beasley, H., Beech, R., Britton, C., Brooks, K., Chaudhry, U., Maitland, K., Martinelli, A., Noonan, J. D., Paulini, M., Quail, M. A., Redman, E., Rodgers, F. H., Sallé, G., Cotton, J. A. (2020). Extensive genomic and transcriptomic variation defines the chromosome-scale assembly of Haemonchus contortus, a model gastrointestinal worm. BioRxiv, https://doi.org/10.1101/2020.02.18.945246

[12] Fu, S., Gao, Z., Birchler, J., \& Han, F. (2012). Dicentric Chromosome Formation and Epigenetics of Centromere Formation in Plants. Journal of Genetics and Genomics, 39(3), 125-130. https://doi.org/10.1016/j.jgg.2012.01.006

[13] Pluta, A. F., Mackay, A. M., Ainsztein, A. M., Goldberg, I. G., \& Earnshaw, W. C. (1995). The centromere: Hub of chromosomal activities. Science, 270(5242), 1591-1594. https://doi.org/10.1126/science.270.5242.1591

[14] Ekwall, K. (2007). Epigenetic control of centromere behavior. Annu Rev Genet, 41, 6381.

https://doi.org/10.1146/annurev.genet.41.1103 06.130127 
[15] Clarke, L. (1990). Centromeres of budding and fission yeasts. Trends Genet, 6(5), 150-154. https://doi.org/10.1016/0168-9525(90)90149-Z

[16] Stoler, S., Keith, K. C., Curnick, K. E., \& Fitzgerald-Hayes, M. (1995). A mutation in CSE4, an essential gene encoding a novel chromatin-associated protein in yeast, causes chromosome nondisjunction and cell cycle arrest at mitosis. Genes Dev., 9(5), 573-586. https://doi.org/10.1101/gad.9.5.573

[17] McGrew, J., Diehl, B., \& Fitzgerald-Hayes, M. (1986). Single base-pair mutations in centromere element III cause aberrant chromosome segregation in Saccharomyces cerevisiae. Mol Cell Biol, 6(2), 530-538. https://doi.org/10.1128/mcb.6.2.530

[18] Wrensch, D. L., Kethley, J. B., \& Norton, R. A. (1994). Cytogenetics of Holokinetic Chromosomes and Inverted Meiosis: Keys to the Evolutionary Success of Mites, with Generalizations on Eukaryotes. Springer, 282343. https://doi.org/10.1007/978-1-4615-23895_11

[19] Mandrioli, M., \& Manicardi, G. C. (2012). Unlocking holocentric chromosomes: New perspectives from comparative and functional genomics? Curr. Genomics, 13(5), 343-349. https://doi.org/10.2174/138920212801619250

[20] Voullaire, L., Saffery, R., Earle, E., Irvine, D. V., Slater, H., Dale, S., Sart, D. du, Fleming, T., \& Choo, K. H. A. (2001). Mosaic inv dup( $8 p$ ) marker chromosome with stable neocentromere suggests neocentromerization is a post-zygotic event. American Journal of Medical Genetics, 102(1), 86-94. https://doi.org/10.1002/1096-

8628(20010722)102:1<86::AIDAJMG1390>3.0.CO;2-T

[21] Nasuda, S., Hudakova, S., Schubert, I., Houben, A., \& Endo, T. R. (2005). Stable barley chromosomes without centromeric repeats. Proc. Natl. Acad. Sci. U.S.A., 102(28), 98429847.

https://doi.org/10.1073/pnas.0504235102

[22] Peacock, W. J., Dennis, E. S., Rhoades, M. M., \& Pryor, A. J. (1981). Highly repeated DNA sequence limited to knob heterochromatin in maize. PNAS, 78(7), 4490-4494. https://doi.org/10.1073/pnas.78.7.4490

[23] Thomas, C. A. (1971). The genetic organization of chromosomes. Annu. Rev. Genet., 5, 237-256. https://doi.org/10.1146/annurev.ge.05.120171. 001321

[24] Choo, K. H. (1997). Centromere DNA dynamics: Latent centromeres and neocentromere formation. American Journal of Human Genetics, 61(6), 1225-1233. https://doi.org/10.1086/301657

[25] Bennetzen, J. L., \& Wang, H. (2014). The Contributions of Transposable Elements to the
Structure, Function, and Evolution of Plant Genomes. Annual Review of Plant Biology, 65(1), 505-530.

https://doi.org/10.1146/annurev-arplant050213-035811

[26] Talbert, P. B., \& Henikoff, S. (2020). What makes a centromere? Experimental Cell Research, 389(2), 111895.

https://doi.org/10.1016/j.yexcr.2020.111895

[27] Ohno. (1972). Ohno "Junk" DNA paper in full, 1972. http://www.junkdna.com/ohno.html

[28] Grewal, S. I. S., \& Elgin, S. C. R. (2007). Transcription and RNA interference in the formation of heterochromatin. Nature, 447(7143), 399-406. https://doi.org/10.1038/nature05914

[29] Plohl, M. (2010). Those mysterious sequences of satellite DNAs. Periodicum Biologorum, 112, 403-410.

[30] Harrison, G. E., \& Heslop-Harrison, J. S. (1995). Centromeric repetitive DNA sequences in the genus Brassica. Theoret. Appl. Genetics, 90(2), 157-165. https://doi.org/10.1007/BF00222197

[31] Plohl, M., Meštrović, N., \& Mravinac, B. (2014). Centromere identity from the DNA point of view. Chromosoma, 123(4), 313-325. https://doi.org/10.1007/s00412-014-0462-0

[32] Iwata, A., Tek, A. L., Richard, M. M. S., Abernathy, B., Fonsêca, A., Schmutz, J., Chen, N. W. G., Thareau, V., Magdelenat, G., Li, Y., Murata, M., Pedrosa-Harand, A., Geffroy, V., Nagaki, K., \& Jackson, S. A. (2013). Identification and characterization of functional centromeres of the common bean. The Plant Journal, 76(1), 47-60. https://doi.org/10.1111/tpj.12269

[33] Kunze, R., Saedler, H., \& Lönnig, W.-E. (1997). Plant Transposable Elements. J. A. Callow (Ed.), Advances in Botanical Research (C. 27, ss. 331-470). https://doi.org/10.1016/S00652296(08)60284-0

[34] Macas, J., Neumann, P., \& Navrátilová, A. (2007). Repetitive DNA in the pea (Pisum sativum L.) genome: Comprehensive characterization using 454 sequencing and comparison to soybean and Medicago truncatula. BMC Genomics, 8, 427. https://doi.org/10.1186/1471-2164-8-427

[35] Nagaki, K., Neumann, P., Zhang, D., Ouyang, S., Buell, C. R., Cheng, Z., \& Jiang, J. (2005). Structure, Divergence, and Distribution of the CRR Centromeric Retrotransposon Family in Rice. Mol Biol Evol, 22(4), 845-855. https://doi.org/10.1093/molbev/msi069

[36] Zhong, C. X., Marshall, J. B., Topp, C., Mroczek, R., Kato, A., Nagaki, K., Birchler, J. A., Jiang, J., \& Dawe, R. K. (2002). Centromeric Retroelements and Satellites Interact with Maize Kinetochore Protein CENH3. The Plant 
Cell, 14(11), 2825-2836. https://doi.org/10.1105/tpc.006106

[37] Lim, K.B., Yang, T.J., Hwang, Y.J., Kim, J. S., Park, J.Y., Kwon, S.J., Kim, J., Choi, B.S., Lim, M.H., Jin, M., Kim, H.I., Jong, H. de, Bancroft, I., Lim, Y., \& Park, B.S. (2007). Characterization of the centromere and pericentromere retrotransposons in Brassica rapa and their distribution in related Brassica species. The Plant Journal, 49(2), 173-183. https://doi.org/10.1111/j.1365-

313X.2006.02952.x

[38] Tek, A.L., Kashihara, K., Murata, M., \& Nagaki, K. (2010). Functional centromeres in soybean include two distinct tandem repeats and a retrotransposon. Chromosome Res, 18(3), 337347. https://doi.org/10.1007/s10577-010-9119$\mathrm{x}$

[39] Nagaki, K., Song, J., Stupar, R. M., Parokonny, A. S., Yuan, Q., Ouyang, S., Liu, J., Hsiao, J., Jones, K. M., Dawe, R. K., Buell, C. R., \& Jiang, J. (2003). Molecular and cytological analyses of large tracks of centromeric DNA reveal the structure and evolutionary dynamics of maize centromeres. Genetics, 163(2), 759770 .

[40] Schmidt, T., \& Heslop-Harrison, J. S. (1998). Genomes, genes and junk: The large-scale organization of plant chromosomes. Trends in Plant Science, 3(5), 195-199. https://doi.org/10.1016/S13601385(98)01223-0

[41] Mehrotra, S., \& Goyal, V. (2014). Repetitive Sequences in Plant Nuclear DNA: Types, Distribution, Evolution and Function. Genomics, Proteomics \& Bioinformatics, 12(4), 164-171. https://doi.org/10.1016/j.gpb.2014.07.003

[42] John, H. A., Birnstiel, M. L., \& Jones, K. W. (1969). RNA-DNA hybrids at the cytological level. Nature, 223(5206), 582-587. https://doi.org/10.1038/223582a0

[43] Biscotti, M. A., Olmo, E., \& Heslop-Harrison, J. S. (Pat). (2015). Repetitive DNA in eukaryotic genomes. Chromosome Res, 23(3), 415-420. https://doi.org/10.1007/s10577-015-9499-z

[44] Charlesworth, B., Sniegowski, P., \& Stephan, W. (1994). The evolutionary dynamics of repetitive DNA in eukaryotes. Nature, 371(6494), 215-220. https://doi.org/10.1038/371215a0

[45] Tek, A. L., \& Jiang, J. (2004). The centromeric regions of potato chromosomes contain megabase-sized tandem arrays of telomeresimilar sequence. Chromosoma, 113(2), 77-83. https://doi.org/10.1007/s00412-004-0297-1

[46] Tek, A. L., Song, J., Macas, J., \& Jiang, J. (2005). Sobo, a Recently Amplified Satellite Repeat of Potato, and Its Implications for the Origin of Tandemly Repeated Sequences. Genetics,
170(3), 1231-1238.

https://doi.org/10.1534/genetics.105.041087

[47] Heslop-Harrison, J. S., Brandes, A., \& Schwarzacher, T. (2003). Tandemly repeated DNA sequences and centromeric chromosomal regions of Arabidopsis species. Chromosome Res, 11(3), 241-253. https://doi.org/10.1023/A:1022998709969

[48] Zhang, X., Li, X., Marshall, J. B., Zhong, C. X., \& Dawe, R. K. (2005). Phosphoserines on Maize Centromeric histone H3 and Histone H3 Demarcate the Centromere and Pericentromere during Chromosome Segregation. The Plant Cell, 17(2), 572-583. https://doi.org/10.1105/tpc.104.028522

[49] Birchler, J. A., \& Han, F. (2009). Maize Centromeres: Structure, Function, Epigenetics. Annu. Rev. Genet, 43(1), 287-303. https://doi.org/10.1146/annurev-genet102108-134834

[50] Tek, A. L., Kashihara, K., Murata, M., \& Nagaki, K. (2011). Functional centromeres in Astragalus sinicus include a compact centromere-specific histone $\mathrm{H} 3$ and a 20-bp tandem repeat. Chromosome Res, 19(8), 969978. https://doi.org/10.1007/s10577-011-9247$\mathrm{y}$

[51] Lee, H. R., Zhang, W., Langdon, T., Jin, W., Yan, H., Cheng, Z., \& Jiang, J. (2005). Chromatin immunoprecipitation cloning reveals rapid evolutionary patterns of centromeric DNA in Oryza species. Proc. Natl. Acad. Sci. U.S.A., 102(33), 11793-11798. https://doi.org/10.1073/pnas.0503863102

[52] Cheng, Z., Dong, F., Langdon, T., Ouyang, S., Buell, C. R., Gu, M., Blattner, F. R., \& Jiang, J. (2002). Functional Rice Centromeres Are Marked by a Satellite Repeat and a Centromere-Specific Retrotransposon. The Plant Cell, 14(8), 1691-1704. https://doi.org/10.1105/tpc.003079

[53] Gill, N., Findley, S., Walling, J. G., Hans, C., Ma, J., Doyle, J., Stacey, G., \& Jackson, S. A. (2009). Molecular and Chromosomal Evidence for Allopolyploidy in Soybean. Plant Physiology, 151(3), 1167-1174. https://doi.org/10.1104/pp.109.137935

[54] Liu, Q., Chang, S., Hartman, G. L., \& Domier, L. L. (2018). Assembly and annotation of a draft genome sequence for Glycine latifolia, a perennial wild relative of soybean. Plant $J$, 95(1), 71-85. https://doi.org/10.1111/tpj.13931

[55] Mehrotra, S., Goel, S., Sharma, S., Raina, S. N., \& Rajpal, V. R. (2013). Sequence analysis of $K p n I$ repeat sequences to revisit the phylogeny of the Genus Carthamus L. Appl. Biochem. Biotechnol, 169(4), 1109-1125. https://doi.org/10.1007/s12010-012-0063-4

[56] Silva, D. M. Z. A., Pansonato-Alves, J. C., 
Utsunomia, R., Daniel, S. N., Hashimoto, D. T., Oliveira, C., Porto-Foresti, F., \& Foresti, F. (2013). Chromosomal organization of repetitive DNA sequences in Astyanax bockmanni (Teleostei, Characiformes): Dispersive location, association and colocalization in the genome. Genetica, 141(7-9), 329-336. https://doi.org/10.1007/s10709-0139732-7

[57] Keçeli, B. N., Jin, C., Van Damme, D., \& Geelen, D. (2020). Conservation of centromeric histone 3 interaction partners in plants. J Exp Bot, 71(17), 5237-5246. https://doi.org/10.1093/jxb/eraa214

[58] Macas, J., Požárková, D., Navrátilová, A., Nouzová, M., \& Neumann, P. (2000). Two new families of tandem repeats isolated from genus Vicia using genomic self-priming PCR. Mol Gen Genet, 263(5), 741-751. https://doi.org/10.1007/s004380000245

[59] Nagaki, K., Talbert, P. B., Zhong, C. X., Dawe, R. K., Henikoff, S., \& Jiang, J. (2003). Chromatin immunoprecipitation reveals that the 180-bp satellite repeat is the key functional DNA element of Arabidopsis thaliana centromeres. Genetics, 163(3), 1221-1225.

[60] Novák, P., Neumann, P., Pech, J., Steinhaisl, J., \& Macas, J. (2013). RepeatExplorer: A Galaxybased web server for genome-wide characterization of eukaryotic repetitive elements from next-generation sequence reads. Bioinformatics , 29(6), 792-793. https://doi.org/10.1093/bioinformatics/btt054

[61] Earnshaw, W. C., \& Rothfield, N. (1985). Identification of a family of human centromere proteins using autoimmune sera from patients with scleroderma. Chromosoma, 91(3), 313321. https://doi.org/10.1007/BF00328227

[62] Palmer, D. K., O’Day, K., Wener, M. H., Andrews, B. S., \& Margolis, R. L. (1987). A 17-kD centromere protein (CENP-A) copurifies with nucleosome core particles and with histones. $J$ Cell Biol, 104(4), 805-815. https://doi.org/10.1083/jcb.104.4.805

[63] Yu, H. G., Dawe, R. K., Hiatt, E. N., \& Dawe, R. K. (2000). The plant kinetochore. Trends in Plant Science, 5(12), 543-547. https://doi.org/10.1016/S1360-1385(00)01789-1

[64] Jiang, J., Birchler, J. A., Parrott, W. A., \& Kelly Dawe, R. (2003). A molecular view of plant centromeres. Trends in Plant Science, 8(12), 570-575. https://doi.org/10.1016/j.tplants.2003.10.011

[65] Warburton, P. E., Cooke, C. A., Bourassa, S., Vafa, O., Sullivan, B. A., Stetten, G., Gimelli, G., Warburton, D., Tyler-Smith, C., Sullivan, K. F., Poirier, G. G., \& Earnshaw, W. C. (1997). Immunolocalization of CENP-A suggests a distinct nucleosome structure at the inner kinetochore plate of active centromeres. Current Biology, 7(11), 901-904. https://doi.org/10.1016/s0960-9822(06)003824

[66] Nagaki, K., Cheng, Z., Ouyang, S., Talbert, P. B., Kim, M., Jones, K. M., Henikoff, S., Buell, C. R., \& Jiang, J. (2004). Sequencing of a rice centromere uncovers active genes. Nat. Genet., 36(2), 138-145. https://doi.org/10.1038/ng1289

[67] Tek, A. L., Kashihara, K., Murata, M., \& Nagaki, K. (2014). Identification of the centromerespecific histone $\mathrm{H} 3$ variant in Lotus japonicus. Gene, 538(1), 8-11. https://doi.org/10.1016/j.gene.2014.01.034

[68] Tek, A. L., \& Kara S. D. Ö. (2020). High allelic diversity of the centromere-specific histone $\mathrm{H} 3$ (CENH3) in the legume sainfoin (Onobrychis viciifolia). Mol Biol Rep. https://doi.org/10.1007/s11033-020-05926-1

[69] Sullivan, K. F., Hechenberger, M., \& Masri, K. (1994). Human CENP-A contains a histone H3 related histone fold domain that is required for targeting to the centromere. J Cell Biol, 127(3), 581-592. https://doi.org/10.1083/jcb.127.3.581

[70] Maheshwari, S., Tan, E. H., West, A., Franklin, F. C. H., Comai, L., \& Chan, S. W. L. (2015). Naturally occurring differences in CENH3 affect chromosome segregation in zygotic mitosis of hybrids. PLoS Genetics, 11(1), e1004970. https://doi.org/10.1371/journal.pgen.1004970

[71] Dawe, R. K., Reed, L. M., Yu, H. G., Muszynski, M. G., \& Hiatt, E. N. (1999). A maize homolog of mammalian CENPC is a constitutive component of the inner kinetochore. Plant Cell, 11(7), 1227-1238.

https://www.ncbi.nlm.nih.gov/pmc/articles/P MC144275/

[72] Ogura, Y., Shibata, F., Sato, H., \& Murata, M. (2004). Characterization of a CENP-C homolog in Arabidopsis thaliana. Genes \& Genetic Systems, 79(3), 139-144. https://doi.org/10.1266/ggs.79.139

[73] Ravi, M., \& Chan, S. W. L. (2010). Haploid plants produced by centromere-mediated genome elimination. Nature, 464(7288), 615-618. https://doi.org/10.1038/nature08842

[74] Douglas, R. N., \& Birchler, J. A. (2013). Plant Centromere Epigenetics. Plant Centromere Biology (ss. 147-158). John Wiley \& Sons, Ltd. https://doi.org/10.1002/9781118525715.ch11

[75] Gent, J. I., Dong, Y., Jiang, J., \& Dawe, R. K. (2012). Strong epigenetic similarity between maize centromeric and pericentromeric regions at the level of small RNAs, DNA methylation and $\mathrm{H} 3$ chromatin modifications. Nucleic Acids Research, 40(4), 1550-1560. https://doi.org/10.1093/nar/gkr862

[76] Strahl, B. D., \& Allis, C. D. (2000). The language 
of covalent histone modifications. Nature, 403(6765), 41-45.

https://doi.org/10.1038/47412

[77] Demidov, D., Heckmann, S., Weiss, O., Rutten, T., Dvořák Tomaštíková, E., Kuhlmann, M., Scholl, P., Municio, C. M., Lermontova, I., \& Houben, A. (2019). Deregulated Phosphorylation of CENH3 at Ser65 Affects the Development of Floral Meristems in Arabidopsis thaliana. Front Plant Sci, 10. https://doi.org/10.3389/fpls.2019.00928

[78] Zhang, W., Lee, H.-R., Koo, D.-H., \& Jiang, J. (2008). Epigenetic Modification of Centromeric Chromatin: Hypomethylation of DNA Sequences in the CENH3-Associated Chromatin in Arabidopsis thaliana and Maize. Plant Cell, 20(1), 25-34. https://doi.org/10.1105/tpc.107.057083

[79] Yan, H., Kikuchi, S., Neumann, P., Zhang, W., Wu, Y., Chen, F., \& Jiang, J. (2010). Genome-wide mapping of cytosine methylation revealed dynamic DNA methylation patterns associated with genes and centromeres in rice. Plant Journal, 63(3), 353-365. https://doi.org/10.1111/j.1365313X.2010.04246.X

[80] Wu, Y., Kikuchi, S., Yan, H., Zhang, W., Rosenbaum, H., Iniguez, A. L., \& Jiang, J. (2011). Euchromatic Subdomains in Rice Centromeres Are Associated with Genes and Transcription. Plant Cell, 23(11), 4054-4064. https://doi.org/10.1105/tpc.111.090043

[81] McClintock, B. (1956). Controlling Elements and the Gene. Cold Spring Harbor Symposia on Quantitative Biology, 21, 197-216. https://doi.org/10.1101/SQB.1956.021.01.017

[82] Talbert, P. B., \& Henikoff, S. (2018). Transcribing Centromeres: Noncoding RNAs and Kinetochore Assembly. Trends in Genet, 34(8), 587-599. https://doi.org/10.1016/j.tig.2018.05.001

[83] Topp, C. N., Zhong, C. X., \& Dawe, R. K. (2004). Centromere-encoded RNAs are integral components of the maize kinetochore. PNAS, 101(45), 15986-15991. https://doi.org/10.1073/pnas.0407154101

[84] May, B. P., Lippman, Z. B., Fang, Y., Spector, D. L., \& Martienssen, R. A. (2005). Differential Regulation of Strand-Specific Transcripts from Arabidopsis Centromeric Satellite Repeats. PLoS Genetics, 1(6). https://doi.org/10.1371/journal.pgen.0010079

[85] Yan, H., Ito, H., Nobuta, K., Ouyang, S., Jin, W., Tian, S., Lu, C., Venu, R. C., Wang, G., Green, P. J., Wing, R. A., Buell, C. R., Meyers, B. C., \& Jiang, J. (2006). Genomic and Genetic Characterization of Rice Cen3 Reveals Extensive Transcription and Evolutionary Implications of a Complex Centromere. Plant Cell, 18(9), 2123-2133. https://doi.org/10.1105/tpc.106.043794

[86] Han, F., Gao, Z., \& Birchler, J. A. (2009). Reactivation of an Inactive Centromere Reveals Epigenetic and Structural Components for Centromere Specification in Maize. Plant Cell, 21(7), 1929-1939. https://doi.org/10.1105/tpc.109.066662

[87] Dunwell, J. M. (2010). Haploids in flowering plants: Origins and exploitation. Plant Biotechnology Journal, 8(4), 377-424. https://doi.org/10.1111/j.14677652.2009.00498.x

[88] Dwivedi, S. L., Britt, A. B., Tripathi, L., Sharma, S., Upadhyaya, H. D., \& Ortiz, R. (2015). Haploids: Constraints and opportunities in plant breeding. Biotechnology Advances, 33(6, Part 1), 812-829. https://doi.org/10.1016/j.biotechadv.2015.07.0 01

[89] Ishii, T., Karimi-Ashtiyani, R., \& Houben, A. (2016). Haploidization via Chromosome Elimination: Means and Mechanisms. Annual Review of Plant Biology, 67(1), 421-438. https://doi.org/10.1146/annurev-arplant043014-114714

[90] Ravi, M., \& Chan, S. W.-L. (2013). CentromereMediated Generation of Haploid Plants. Plant Centromere Biology (ss. 169-181). John Wiley \& Sons, Ltd. https://doi.org/10.1002/9781118525715.ch13

[91] Kuppu, S., Ron, M., Marimuthu, M. P. A., Li, G., Huddleson, A., Siddeek, M. H., Terry, J., Buchner, R., Shabek, N., Comai, L., \& Britt, A. B. (2020). A variety of changes, including CRISPR/Cas9-mediated deletions, in CENH3 lead to haploid induction on outcrossing. Plant Biotechnol J, pbi.13365. https://doi.org/10.1111/pbi.13365

[92] Kalinowska, K., Chamas, S., Unkel, K., Demidov, D., Lermontova, I., Dresselhaus, T., Kumlehn, J., Dunemann, F., \& Houben, A. (2019). Stateof-the-art and novel developments of in vivo haploid technologies. Theor Appl Genet, 132(3), 593-605. https://doi.org/10.1007/s00122-018-3261-9

[93] Tek, A. L., Stupar, R. M., \& Nagaki, K. (2015). Modification of centromere structure: A promising approach for haploid line production in plant breeding. Turk J Agric For, 39(4), 557562.

http://journals.tubitak.gov.tr/agriculture/abstra ct.htm?id=16664

[94] Kelliher, T., Starr, D., Wang, W., McCuiston, J., Zhong, H., Nuccio, M. L., \& Martin, B. (2016). Maternal Haploids Are Preferentially Induced by CENH3-tailswap Transgenic Complementation in Maize. Front. Plant Sci., 7. https://doi.org/10.3389/fpls.2016.00414

[95] De Storme, N., Keçeli, B. N., Zamariola, L., Angenon, G., \& Geelen, D. (2016). CENH3- 
GFP: A visual marker for gametophytic and somatic ploidy determination in Arabidopsis thaliana. BMC Plant Biol, 16, 1. https://doi.org/10.1186/s12870-015-0700-5

[96] Cuacos, M., H Franklin, F. C., \& Heckmann, S. (2015). Atypical centromeres in plants-what they can tell us. Front Plant Sci, 6, 913. https://doi.org/10.3389/fpls.2015.00913

[97] Martinez-Zapater, J. M., Estelle, M. A., \& Somerville, C. R. (1986). A highly repeated DNA sequence in Arabidopsis thaliana. Molec Gen Genet, 204(3), 417-423. https://doi.org/10.1007/BF00331018

[98] Murata, M., Ogura, Y., \& Motoyoshi, F. (1994). Centromeric repetitive sequences in Arabidopsis thaliana. Jpn J Genet, 69(4), 361370. https://doi.org/10.1266/jjg.69.361

[99] Koukalová, B., Komarnitsky, I. K., \& Kuhrová, V. (1993). The distribution of tobacco HRS60 DNA repeated sequences in species of the genus Nicotiana. Plant Science, 88(1), 39-44. https://doi.org/10.1016/0168-9452(93)90107-B

[100] Ohmido, N., Ishimaru, A., Kato, S., Sato, S., Tabata, S., \& Fukui, K. (2010). Integration of cytogenetic and genetic linkage maps of Lotus japonicus, a model plant for legumes. Chromosome Res, 18(2), 287-299. https://doi.org/10.1007/s10577-009-9103-5

[101] Kulikova, O., Geurts, R., Lamine, M., Kim, D. J., Cook, D. R., Leunissen, J., de Jong, H., Roe, B. A., \& Bisseling, T. (2004). Satellite repeats in the functional centromere and pericentromeric heterochromatin of Medicago truncatula. Chromosoma, 113(6), 276-283. https://doi.org/10.1007/s00412-004-0315-3

[102] Neumann, P., Nouzová, M., \& Macas, J. (2001). Molecular and cytogenetic analysis of repetitive DNA in pea (Pisum sativum L.). Genome, 44(4), 716-728.

[103] Neumann, P., Navrátilová, A., Schroeder-Reiter, E., Koblížková, A., Steinbauerová, V., Chocholová, E., Novák, P., Wanner, G., \& Macas, J. (2012). Stretching the rules: Monocentric chromosomes with multiple centromere domains. PLoS Genetics, 8(6), e1002777. https://doi.org/10.1371/journal.pgen.1002777

[104] Galasso, I., Pignone, D. R., Harrison, G. E., Heslop Harrison, J. S (1999). Location of two repeated DNA sequences of Vigna unguiculata (L.) Walp. On chromosomes and extended DNA fibres by FISH. Journal of Genetics \& Breeding (Italy).

[105] Iwata-Otsubo, A., Radke, B., Findley, S., Abernathy, B., Vallejos, C. E., \& Jackson, S. A. (2016). Fluorescence In Situ Hybridization
(FISH)-Based Karyotyping Reveals Rapid Evolution of Centromeric and Subtelomeric Repeats in Common Bean (Phaseolus vulgaris) and Relatives. G3 (Bethesda), 6(4), 1013-1022. https://doi.org/10.1534/g3.115.024984

[106] Ishii, T., Juranić, M., Maheshwari, S., Bustamante, F. de O., Vogt, M. M., SalinasGamboa, R., Dreissig, S., Gursanscky, N., How, T., Fuchs, J., Schubert, V., Spriggs, A., Vielle-Calzada, J. P., Comai, L., Koltunow, A. M. G., \& Houben, A. (2020). Unequal contribution of two paralogous centromeric histones to function the cowpea centromere. BioRxiv, 2020.01.07.897074. https://doi.org/10.1101/2020.01.07.897074

[107] Vahedian, M., Shi, L., Zhu, T., Okimoto, R., Danna, K., \& Keim, P. (1995). Genomic organization and evolution of the soybean SB92 satellite sequence. Plant Molecular Biology, 29(4), 857-862. https://doi.org/10.1007/BF00041174

[108 Morgante, M., Jurman, I., Shi, L., Zhu, T., Keim, P., \& Rafalski, J. A. (1997). The STR120 satellite DNA of soybean: Organization, evolution and chromosomal specificity. Chromosome Res, 5(6), 363-373. https://doi.org/10.1023/A:1018492208247

[109] Lin, J.-Y., Jacobus, B. H., SanMiguel, P., Walling, J. G., Yuan, Y., Shoemaker, R. C., Young, N. D., \& Jackson, S. A. (2005). Pericentromeric regions of soybean (Glycine max L. Merr.) chromosomes consist of retroelements and tandemly repeated DNA and are structurally and evolutionarily labile. Genetics, 170(3), 1221-1230. https://doi.org/10.1534/genetics.105.041616

[110] Heckmann, S., Macas, J., Kumke, K., Fuchs, J., Schubert, V., Ma, L., Novák, P., Neumann, P., Taudien, S., Platzer, M., \& Houben, A. (2013). The holocentric species Luzula elegans shows interplay between centromere and large-scale genome organization. Plant J, 73(4), 555-565. https://doi.org/10.1111/tpj.12054

[111]Neumann, P., Schubert, V., Fuková, I., Manning, J. E., Houben, A., \& Macas, J. (2016). Epigenetic Histone Marks of Extended MetaPolycentric Centromeres of Lathyrus and Pisum Chromosomes. Front Plant Sci, 7, 234. https://doi.org/10.3389/fpls.2016.00234

[112] Öztürk, S. D. K., Yıldırım, B. Ş., Yıldız, H., \& Tek, A. L. (2021). Geçmişten günümüze genetik ve kromozom mühendisliği çalışmalarının sürdürülebilir tarım ve bitki 1slahına katkıs1. YYÜ Tar Bil Der, 31(1), 246258. https://doi.org/10.29133/yyutbd.787094 